\title{
Northern Hemisphere atmospheric influence of the solar proton events and ground level enhancement in January 2005
}

\author{
C. H. Jackman ${ }^{1}$, D. R. Marsh ${ }^{2}$, F. M. Vitt ${ }^{2}$, R. G. Roble ${ }^{2}$, C. E. Randall ${ }^{3}$, P. F. Bernath ${ }^{4}$, B. Funke ${ }^{5}$, \\ M. López-Puertas ${ }^{5}$, S. Versick ${ }^{6}$, G. P. Stiller ${ }^{6}$, A. J. Tylka ${ }^{7}$, and E. L. Fleming ${ }^{1,8}$ \\ ${ }^{1}$ NASA Goddard Space Flight Center, Greenbelt, Maryland, USA \\ ${ }^{2}$ National Center for Atmospheric Research, Boulder, Colorado, USA \\ ${ }^{3}$ University of Colorado, Boulder, Colorado, USA \\ ${ }^{4}$ University of York, York, UK \\ ${ }^{5}$ Instituto de Astrofisica de Andalucia, CSIC, Granada, Spain \\ ${ }^{6}$ Karlsruhe Institute of Technology, Karlsruhe, Germany \\ ${ }^{7}$ Naval Research Laboratory, Washington, DC, USA \\ ${ }^{8}$ Science Systems and Applications Inc., Lanham, Maryland, USA
}

Received: 6 January 2011 - Published in Atmos. Chem. Phys. Discuss.: 7 March 2011

Revised: 13 June 2011 - Accepted: 17 June 2011 - Published: 1 July 2011

\begin{abstract}
Solar eruptions in early 2005 led to a substantial barrage of charged particles on the Earth's atmosphere during the 16-21 January period. Proton fluxes were greatly increased during these several days and led to the production of $\mathrm{HO}_{\mathrm{x}}\left(\mathrm{H}, \mathrm{OH}, \mathrm{HO}_{2}\right)$ and $\mathrm{NO}_{\mathrm{x}}\left(\mathrm{N}, \mathrm{NO}, \mathrm{NO}_{2}\right)$, which then caused the destruction of ozone. We focus on the Northern polar region, where satellite measurements and simulations with the Whole Atmosphere Community Climate Model (WACCM3) showed large enhancements in mesospheric $\mathrm{HO}_{\mathrm{x}}$ and $\mathrm{NO}_{\mathrm{x}}$ constituents, and associated ozone reductions, due to these solar proton events (SPEs). The WACCM3 simulations show enhanced short-lived $\mathrm{OH}$ and $\mathrm{HO}_{2}$ concentrations throughout the mesosphere in the 60$82.5^{\circ} \mathrm{N}$ latitude band due to the SPEs for most days in the 16-21 January 2005 period, somewhat higher in abundance than those observed by the Aura Microwave Limb Sounder (MLS). These $\mathrm{HO}_{\mathrm{x}}$ enhancements led to huge predicted and MLS-measured ozone decreases of greater than $40 \%$ throughout most of the northern polar mesosphere during the SPE period. Envisat Michelson Interferometer for Passive Atmospheric Sounding (MIPAS) measurements of hydrogen peroxide $\left(\mathrm{H}_{2} \mathrm{O}_{2}\right)$ show increases throughout the stratosphere with highest enhancements of about 60 pptv in the lowermost mesosphere over the 16-18 January 2005 period due to the solar protons. WACCM3 predictions indicate $\mathrm{H}_{2} \mathrm{O}_{2}$ enhancements over the same time period of about three
\end{abstract}

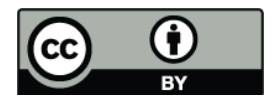

Correspondence to: C. H. Jackman (charles.h.jackman@nasa.gov) times that amount. Measurements of nitric acid $\left(\mathrm{HNO}_{3}\right)$ by both MLS and MIPAS show an increase of about 1 ppbv above background levels in the upper stratosphere during 16-29 January 2005. WACCM3 simulations show only minuscule $\mathrm{HNO}_{3}$ increases $(<0.05 \mathrm{ppbv})$ in the upper stratosphere during this time period. Polar mesospheric enhancements of $\mathrm{NO}_{\mathrm{x}}$ are computed to be greater than $50 \mathrm{ppbv}$ during the SPE period due to the small loss rates during winter. Computed $\mathrm{NO}_{\mathrm{x}}$ increases, which were statistically significant at the $95 \%$ level, lasted about a month past the SPEs. The SCISAT-1 Atmospheric Chemistry Experiment Fourier Transform Spectrometer $\mathrm{NO}_{\mathrm{x}}$ measurements and MIPAS $\mathrm{NO}_{2}$ measurements for the polar Northern Hemisphere are in reasonable agreement with these predictions. An extremely large ground level enhancement (GLE) occurred during the SPE period on 20 January 2005 . We find that protons of energies 300 to $20000 \mathrm{MeV}$, associated with this GLE, led to very small enhanced lower stratospheric odd nitrogen concentrations of less than $0.1 \%$ and ozone decreases of less than $0.01 \%$.

\section{Introduction}

Large solar eruptions during 16-21 January 2005 caused huge fluxes of high-energy solar charged particles to reach Earth. The solar proton flux enhancement during this period has been well documented and caused significant production of OH (Verronen et al., 2006; Damiani et al., 2008) and destruction of ozone (Verronen et al., 2006; Seppälä et al.,

Published by Copernicus Publications on behalf of the European Geosciences Union. 
2006; Klekociuk et al., 2007; Damiani et al., 2008). The largest ground level enhancement (GLE) of neutrons during solar cycle 23 also occurred in this period. A neutron monitor registered an increase of about $270 \%$ on 20 January 2005 during the GLE (Gopalswamy et al., 2005).

We recently studied the short- and medium-term (days to a few months) atmospheric constituent effects of the four largest solar proton events (SPEs) in the past 45 years (August 1972, October 1989, July 2000, and October-November 2003) in Jackman et al. (2008) with version 3 of the Whole Atmosphere Community Climate Model (WACCM3). The present investigation builds on that study and focuses on the short- and medium-term influences of solar particles on the mesosphere and stratosphere in the time period 1 January through 31 March 2005. There was substantial solar activity in January 2005, which was also the period of the eleventh largest SPE period in the past 45 years (Jackman et al., 2008). We include SPEs in January 2005 and the highest energy protons leading to the GLE on 20 January 2005 in our WACCM3 computations. Larger and longer-lasting impacts were expected in the northern winter polar region because of the diminished sunlight and general downward transport. We, therefore, focus on the impact of the solar particles on constituents in the northern polar mesosphere and stratosphere. The highly energetic solar particles produced $\mathrm{HO}_{\mathrm{x}}\left(\mathrm{H}, \mathrm{OH}, \mathrm{HO}_{2}\right)$ and $\mathrm{NO}_{\mathrm{x}}\left(\mathrm{N}, \mathrm{NO}, \mathrm{NO}_{2}\right)$, which then led to ozone variations. We compare the WACCM3 predictions during this period with measurements from three platforms: Aura Microwave Limb Sounder (MLS) of OH, $\mathrm{HO}_{2}, \mathrm{HNO}_{3}$, and ozone; Envisat Michelson Interferometer for Passive Atmospheric Sounding (MIPAS) of $\mathrm{H}_{2} \mathrm{O}_{2}, \mathrm{NO}_{2}$, and $\mathrm{HNO}_{3}$; and SCISAT-1 Atmospheric Chemistry Experiment Fourier Transform Spectrometer (ACE-FTS) of NO and $\mathrm{NO}_{2}$.

This paper is divided into seven sections, including the Introduction. The charged particle flux and ionization rate are discussed in Sect. 2. $\mathrm{HO}_{\mathrm{x}}$ and $\mathrm{NO}_{\mathrm{x}}$ production are discussed in Sect. 3. A description of WACCM3 is given in Sect. 4. The modeled and measured influences of the January 2005 SPEs over the 1 January-31 March 2005 period are shown in Sect. 5. The influence of the 20 January 2005 GLE is shown in Sect. 6 and the conclusions are presented in Sect. 7.

\section{Charged particle flux and ionization rate}

Our WACCM3 computations with charged particle flux included: (1) the solar proton flux (energies 1 to $300 \mathrm{MeV}$ ) over the 1 January-31 March 2005 period; and (2) the highest energy protons ( 300 to $20000 \mathrm{MeV}$ ) associated with a GLE of neutrons on 20 January 2005. We performed separate WACCM3 simulations with no charged particle flux, charged particles described in (1), and charged particles described in both (1) and (2). These model simulations are described in Sect. 4.

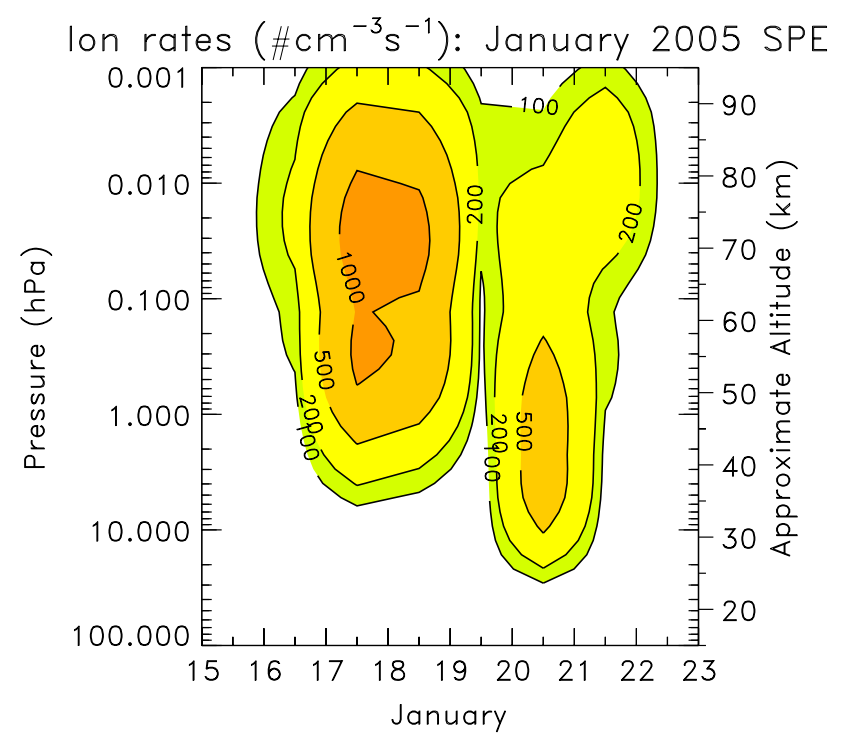

Fig. 1. Daily average ion pair production rates $\left(\# \mathrm{~cm}^{-3} \mathrm{~s}^{-1}\right)$ for the "SPEs-only" case (protons with energy 1-300 MeV) as a function of time for 15-22 January 2005.

The solar proton flux (energies 1 to $300 \mathrm{MeV}$ ) for 2005 was provided by the National Oceanic and Atmospheric Administration (NOAA) Geostationary Operational Environmental Satellite, GOES-11 (Jackman et al., 2008). The proton flux data from the satellite were used to compute ion pair production profiles using the energy deposition methodology discussed in Jackman et al. (1980), where the creation of one ion pair was assumed to require $35 \mathrm{eV}$ (Porter et al., 1976). The SPE-produced daily average ionization rates are given in Fig. 1 for the eight day period, 15-22 January 2005, from $100 \mathrm{hPa}(\sim 16 \mathrm{~km})$ to $0.001 \mathrm{hPa}(\sim 96 \mathrm{~km})$. There were two periods of SPEs in these eight days, 16-18 January and 20-21 January. The first period was the most intense with peak ionization above $1000 \mathrm{~cm}^{-3} \mathrm{~s}^{-1}$ for the 0.01 to $1 \mathrm{hPa}$ region. The second period showed peak ionization above $500 \mathrm{~cm}^{-3} \mathrm{~s}^{-1}$ for the 0.2 to $10 \mathrm{hPa}$ region.

We included the highest energy protons (300 to $20000 \mathrm{MeV}$ ) associated with the GLE of neutrons on 20 January 2005 in some computations with "SPEs + GLE". This high energy proton flux was taken from the spectrum given in Usoskin et al. (2009, 2011), which was derived using methodology presented in Tylka and Dietrich (2009). The calculated GLE ionization rate on 20 January 2005 was added to the computed ionization rate from the GOES-11 measured protons for some of the model computations (see Sect. 4). Ionization rates on 20 January 2005 between 10 and $100 \mathrm{hPa}$ for "SPEs-only" and "SPEs + GLE" are compared in Fig. 2. At $10 \mathrm{hPa}$ the ionization is primarily caused by the SPEs; ionization caused by the GLE rapidly increases in importance below $10 \mathrm{hPa}$, and is more than an order of magnitude larger than ionization by the SPEs at $40 \mathrm{hPa}$. 


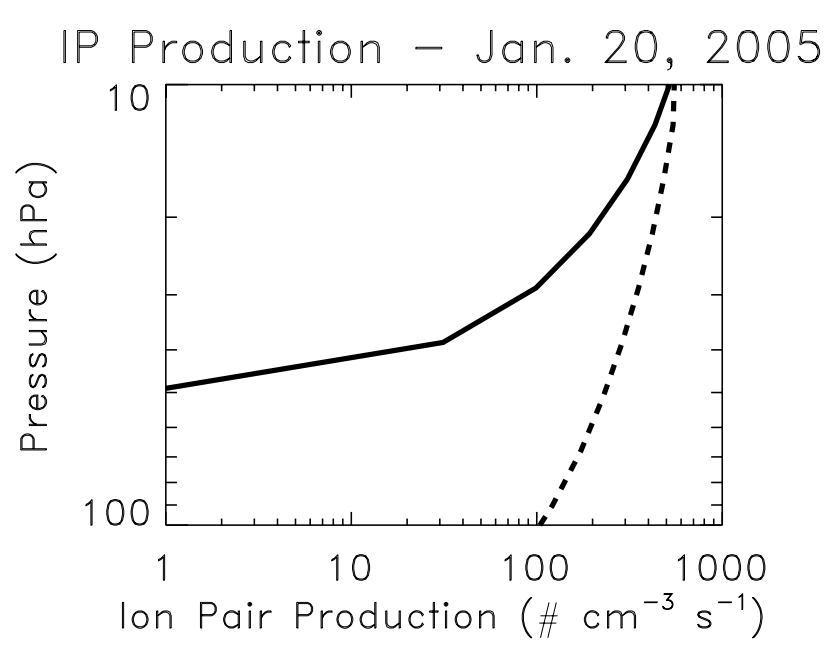

Fig. 2. Daily average ion pair production rates $\left(\mathrm{cm}^{-3} \mathrm{~s}^{-1}\right)$ computed for the "SPEs-only" case (solid line) and the "SPEs + GLE" case (dashed line) on 20 January 2005.

Table 1. Description of WACCM3 simulations.

\begin{tabular}{lcccc}
\hline $\begin{array}{l}\text { Simulation } \\
\text { designation }\end{array}$ & $\begin{array}{c}\text { Number of } \\
\text { realizations }\end{array}$ & $\begin{array}{c}\text { Time } \\
\text { period }\end{array}$ & $\begin{array}{c}\text { SPEs } \\
\text { included }\end{array}$ & $\begin{array}{c}\text { GLE } \\
\text { included }\end{array}$ \\
\hline A $(1,2,3,4)$ & 4 & 1 Jan-31 Mar 2005 & No & No \\
B $(1,2,3,4)$ & 4 & 1 Jan-31 Mar 2005 & Yes & No \\
C $(1,2,3,4)$ & 4 & 1 Jan-31 Mar 2005 & Yes & Yes \\
\hline
\end{tabular}

\section{$3 \quad \mathrm{HO}_{\mathrm{x}}$ and $\mathrm{NO}_{\mathrm{x}}$ production}

Charged particle precipitation results in the production of $\mathrm{HO}_{\mathrm{x}}$ through complex positive ion chemistry (Solomon et al., 1981). The charged particle-produced $\mathrm{HO}_{\mathrm{x}}$ is a function of ion pair production and altitude and is included in WACCM3 simulations using a lookup table from Jackman et al. (2005a, Table 1), which is based on the work of Solomon et al. (1981). Verronen et al. (2006) have noted that $\mathrm{HNO}_{3}$ is produced along with the $\mathrm{HO}_{\mathrm{x}}$, ultimately leading to a delayed production of $\mathrm{HO}_{\mathrm{x}}$. Currently, WACCM3 does not include this production of $\mathrm{HNO}_{3}$ and only includes the $\mathrm{HO}_{\mathrm{x}}$ production. Even though the $\mathrm{HO}_{\mathrm{x}}$ constituents have a relatively short lifetime ( $\sim$ hours) throughout most of the mesosphere, the ozone depletion can be very large during substantial SPEs (e.g., Solomon et al., 1983; Jackman et al., 2001; Verronen et al., 2006). This $\mathrm{HO}_{\mathrm{x}}$-induced ozone depletion can have an influence on the mesospheric temperature and winds over a relatively short period of time ( $\sim 4-6$ weeks), see Jackman et al. (2007).

$\mathrm{NO}_{\mathrm{x}}$ is produced when the energetic charged particles (protons and associated secondary electrons) dissociate $\mathrm{N}_{2}$ as they precipitate into the atmosphere. Here we assume that $\sim 1.25 \mathrm{~N}$ atoms are produced per ion pair and divide the proton impact of $\mathrm{N}$ atom production between ground state
$\mathrm{N}\left({ }^{4} \mathrm{~S}\right)(\sim 45 \%$ or $\sim 0.55$ per ion pair $)$ and excited state $\mathrm{N}\left({ }^{2} \mathrm{D}\right)$ $(\sim 55 \%$ or $\sim 0.7$ per ion pair) nitrogen atoms (Porter et al., 1976). The $\mathrm{N}$ atoms react rapidly with other atmospheric constituents to form $\mathrm{NO}$ and, subsequently, $\mathrm{NO}_{2}$.

\section{Description of the whole atmosphere community climate model (WACCM3)}

WACCM3 has been used in several previous studies to investigate the impact of natural and anthropogenic influences on the atmosphere from the troposphere through the middle atmosphere to the lower thermosphere (Sassi et al., 2002, 2004; Forkman et al., 2003; Richter and Garcia, 2006; Kinnison et al., 2007; Garcia et al., 2007; Marsh et al., 2007; Jackman et al., 2008, 2009). The model domain is from the surface to $4.5 \times 10^{-6} \mathrm{hPa}$ (about $145 \mathrm{~km}$ ), with 66 vertical levels, and includes fully interactive dynamics, radiation, and chemistry. WACCM3 is based on the Community Atmosphere Model (CAM3) and includes modules from the Thermosphere-Ionosphere-Mesosphere-Electrodynamics General Circulation Model (TIME-GCM) and the Model for Ozone And Related chemical Tracers (MOZART-3) to simulate the dynamics and chemistry of the Earth's atmosphere. The vertical resolution is $\leq 1.5 \mathrm{~km}$ between the surface and about $25 \mathrm{~km}$ and increases slowly above $25 \mathrm{~km}$ to $2 \mathrm{~km}$ at the stratopause; it is $3.5 \mathrm{~km}$ in the mesosphere and one half the local scale height above the mesopause. The version of WACCM3 used here has latitude and longitude grid spacing of $4^{\circ}$ and $5^{\circ}$, respectively. An extensive description of WACCM3 is given in Garcia et al. (2007) and Kinnison et al. (2007).

WACCM3 was forced in all simulations with observed time-dependent sea surface temperatures (SSTs), observed solar spectral irradiance and geomagnetic activity changes, and observed concentrations of greenhouse gases and halogen species over the simulation period (see Garcia et al., 2007). The geomagnetic activity included in all the WACCM3 simulations accounts for auroral precipitation, along with $\mathrm{HO}_{\mathrm{x}}$ and $\mathrm{NO}_{\mathrm{x}}$ production. However, these auroral particles mostly deposit their energy in the lower thermosphere (Marsh et al., 2007), whereas SPEs deposit most of their energy in the mesosphere and upper stratosphere. Medium energy electrons (MEEs) also impacted the atmosphere in January 2005. We have started work on including MEEs in future WACCM3 computations, however, the incorporation of MEEs is beyond the scope of the present study.

We have completed three 4-member ensemble WACCM3 simulations (described below) over the 1 January-31 March 2005 period: (A) four realizations $[\mathrm{A}(1,2,3,4)]$ without any daily ionization rates from SPEs or the GLE; (B) four realizations $[\mathrm{B}(1,2,3,4)]$ with the daily ionization rates from SPEs throughout the period; and $(C)$ four realizations $[C(1$, $2,3,4)$ ] with the daily ionization rates from SPEs throughout 
the period and the GLE on 20 January. These WACCM3 simulations are summarized in Table 1.

The ionization rates, when included, were applied uniformly over both polar cap regions $\left(60-90^{\circ} \mathrm{N}\right.$ and $60-90^{\circ} \mathrm{S}$ geomagnetic latitude) as solar protons are guided by the Earth's magnetic field lines to approximately these areas (McPeters et al., 1981; Jackman et al., 2005a). Verronen et al. (2007) show that the geomagnetic boundary can vary with the proton forcing ranging from none to a full affect between about 57 and $64^{\circ} \mathrm{N}$ for the January 2005 SPEs time period. Our assumption of a uniform forcing over the entire polar cap may slightly overestimate the affected area. It does appear from the Verronen et al. study that the proton forcing is nearly a full effect at geomagnetic latitudes greater than about $62-63^{\circ} \mathrm{N}$. If the affected polar cap is $62-90^{\circ} \mathrm{N}$, rather than $60-90^{\circ} \mathrm{N}$, then the impacted area would be decreased by about $13 \%$. Given that the proton flux's impacted region is variable with time and sometimes extends to latitudes lower than $60^{\circ}$ geomagnetic, we have assumed a nonchanging polar cap area for ease of computation. Due to the differing offsets of the geomagnetic and geographic poles in the two hemispheres, the effects from the SPEs and GLE are not expected to be symmetric in the Northern and Southern Hemispheres.

WACCM3 is a free-running GCM and the realizations' starting conditions were each slightly different from the other, initiated in January 1950. For all ensemble members WACCM3 was run in its free-running mode with identical boundary conditions from January 1950 up to 1 January 2005 (Garcia et al., 2007; Jackman et al., 2009), which is the starting date for all model computations shown in this paper. Simulations $\mathrm{A} 1, \mathrm{~B} 1$, and $\mathrm{C} 1$ have the same starting conditions, except simulation A1 has "no SPEs and no GLE", simulation B1 has "SPEs-only", simulation C1 has "SPEs + GLE". Similar comments apply to grouped simulations A2, B2, and $\mathrm{C} 2$; $\mathrm{A} 3, \mathrm{~B} 3$, and $\mathrm{C} 3$; and $\mathrm{A} 4, \mathrm{~B} 4$, and $\mathrm{C} 4$.

The WACCM 3 daily average constituent computations are shown in comparison with measurements in this study.

\section{Influences of the January 2005 SPEs}

The mesosphere was perturbed by the SPEs in January 2005 as seen in the measurements of several satellite instruments and WACCM3 simulations. The short- $(\sim$ days $)$ as well as medium- ( $\sim$ weeks $)$ term changes due to these solar influences will be discussed in this section.

\subsection{Short-term influences}

Since $\mathrm{HO}_{\mathrm{x}}$ constituents have such short lifetimes (e.g., Solomon et al., 1981), a large enhancement of $\mathrm{HO}_{\mathrm{x}}$ caused by an influx of protons during an SPE will be relatively shortlived ( $\sim$ days). MLS provided measurements of two $\mathrm{HO}_{\mathrm{x}}$ constituents, $\mathrm{OH}$ and $\mathrm{HO}_{2}$ (Pickett et al., 2008). Previous pa- pers have shown substantial $\mathrm{HO}_{\mathrm{x}}$ and ozone impacts during the January 2005 SPEs (Verronen et al., 2006, 2007; Seppälä et al., 2006; Klekociuk et al., 2007; Damiani et al., 2008, $2009,2010)$. We focus on the northern polar latitudes, a geographic region where $\mathrm{HO}_{\mathrm{x}}$ constituents are at very small values in January due to minimal or no sunlight. The $\mathrm{HO}_{\mathrm{x}}$ constituents in the winter polar region are, therefore, especially sensitive to solar proton impact in the mesosphere.

\subsubsection{Hydroxyl radical $(\mathrm{OH})$}

The Aura MLS OH measured enhancements due to the SPEs at $0.022 \mathrm{hPa}$ for the Northern Hemisphere are given in Fig. 3 and were computed by subtracting the observations on 15 January 2005 (before the SPE) from the observations on 18 January 2005 (during the SPE). For added clarity, measurements are only shown northward of $42.5^{\circ} \mathrm{N}$, however, no MLS measurements are available in the band $82.5-90^{\circ} \mathrm{N}$. MLS measurements were binned into $30^{\circ}$ longitude and $5^{\circ}$ latitude bands. The polar cap edge $\left(60^{\circ} \mathrm{N}\right.$ geomagnetic latitude), wherein the protons are predicted to interact with the atmosphere, is indicated by the white circle. The MLS data shows that the SPE increased OH significantly: values greater than $4 \mathrm{ppbv}$ are observed in a substantial part of the area poleward of $60^{\circ} \mathrm{N}$ geomagnetic latitude.

The WACCM3 $\mathrm{OH}$ predicted enhancements due to the SPEs at $0.022 \mathrm{hPa}$ for the Northern Hemisphere are given in Fig. 4 and were computed from an average of the B realizations. In particular, the WACCM3 B average results on 15 January 2005 (before the SPE) were subtracted from the WACCM3 B results on 18 January 2005 (during the SPE). The MLS averaging kernel (AK) was also applied to the plotted WACCM3 results. For added clarity, the simulation results are only shown from $44-90^{\circ} \mathrm{N}$. As in Fig. 3, the polar cap edge $\left(60^{\circ}\right.$ geomagnetic latitude) is indicated by the white circle. WACCM3 also predicted a significant increase in $\mathrm{OH}$ : values greater than $4 \mathrm{ppbv}$ are modeled in a substantial part of the area poleward of $60^{\circ} \mathrm{N}$ geomagnetic latitude. Both the MLS measurements and WACCM3 predictions indicate similar areas of enhanced $\mathrm{OH}$ as a result of the SPEs. The WACCM3 predictions do indicate a somewhat larger amount of $\mathrm{OH}$ change, when compared with MLS observations.

We compare the MLS OH measurements and WACCM3 model predictions for 16-23 January 2005 in the latitude band $60-82.5^{\circ} \mathrm{N}$ in Fig. 5. The first two weeks of January 2005 were relatively quiet and contained no SPEs. We thus used these first two weeks (1-14 January) to construct an average quiescent $\mathrm{OH}$ profile for both MLS and WACCM3, respectively. This respective quiescent $\mathrm{OH}$ profile was subtracted from the $\mathrm{OH}$ observations or predictions for 16-23 January 2005 and the results are given in Fig. 5. An average of the WACCM3 B realizations was used for this figure. As in Fig. 4, the MLS AK was applied to the plotted WACCM3 results. 
$\mathrm{OH}(\mathrm{ppbv})=0.022 \mathrm{hPo}-(\mathrm{Jan}, 18$ minus Jon, 15) - MLS
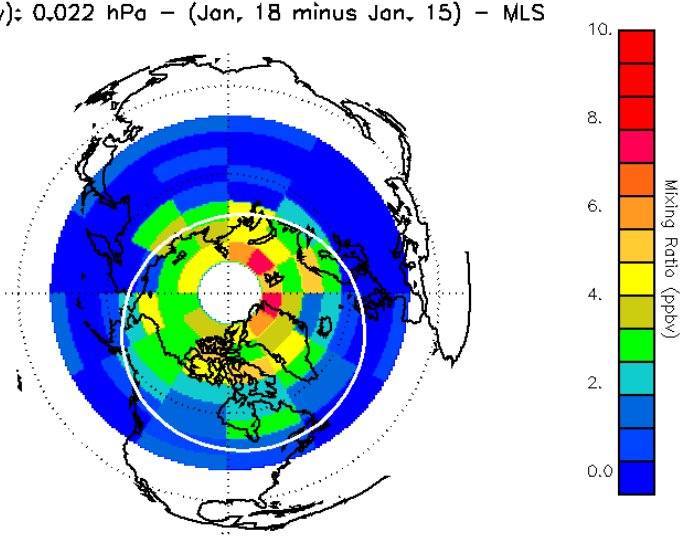

Fig. 3. Aura MLS OH measurements at $0.022 \mathrm{hPa}(\sim 75 \mathrm{~km})$ on 18 January 2005 (after SPE) minus those on 15 January 2005 (before $\mathrm{SPE})$. For added clarity, measurements are only shown in the latitude range $42.5-82.5^{\circ} \mathrm{N}$. No MLS measurements are available at $82.5-90^{\circ} \mathrm{N}$. The polar cap edge $\left(60^{\circ}\right.$ geomagnetic latitude $)$ is indicated by the white circle.

Fairly substantial $\mathrm{OH}$ enhancements are shown in the MLS measurements (up to $4 \mathrm{ppbv}$ ) and WACCM3 predictions (up to $6 \mathrm{ppbv}$ ) for the 16-23 January period. The $\mathrm{OH}$ increases were largest on 17-18 January, similar to the WACCM3 predictions. Similar to the comparisons between Figs. 3 and 4, the WACCM3 predictions of Fig. 5 do indicate a somewhat larger peak $\mathrm{OH}$ change, when compared with MLS observations.

\subsubsection{Hydrogen dioxide $\left(\mathrm{HO}_{2}\right)$}

The MLS instrument additionally provides $\mathrm{HO}_{2}$ measurements during the January 2005 period. Such measurements are somewhat noisier than the $\mathrm{OH}$ observations, however, MLS $\mathrm{HO}_{2}$ does indicate enhancements above background levels ( $>0.1 \mathrm{ppbv}$ ) due to the January 2005 SPEs. Similar to Fig. 5, Fig. 6 was produced by averaging the $\mathrm{HO}_{2}$ measurements over the quiet (non-SPE) period 1-14 January 2005 and subtracting this average from the $\mathrm{HO}_{2}$ observations or predictions during 16-23 January 2005. Again, an average of the WACCM3 B realizations sampled with the MLS AK was used for Fig. 6.

As with $\mathrm{OH}$, the WACCM3 predictions indicate a similar time frame for the $\mathrm{HO}_{2}$ atmospheric perturbation when compared with MLS observations. Also, a somewhat larger $\mathrm{HO}_{2}$ change is predicted than measured in the 16-21 January 2005 time period. The cause of the modeled/measured SPE-caused $\mathrm{OH}$ and $\mathrm{HO}_{2}$ differences is not clear, but may be related to problems in the modeled representation of $\mathrm{HO}_{\mathrm{x}}$ chemistry (Canty et al., 2006).
$\mathrm{OH}$ (ppbv) $0.022 \mathrm{hPo}$ (Jon, 18 minus Jon, 15) - WACCM $(B)$
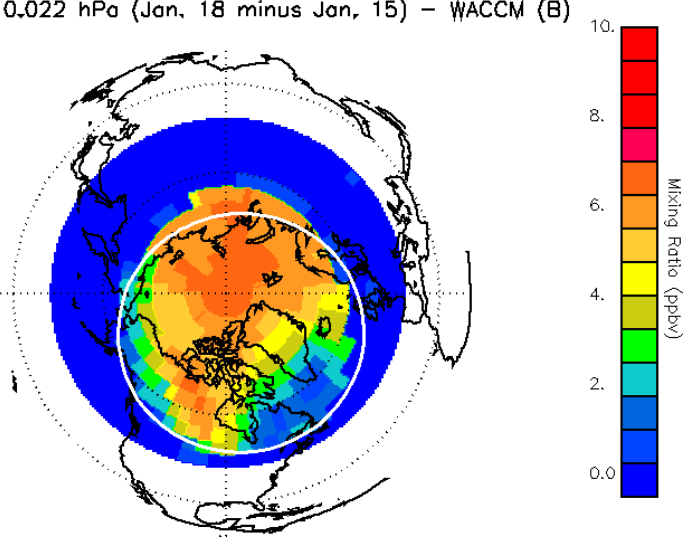

Fig. 4. WACCM3 B average $\mathrm{OH}$ predictions at $0.022 \mathrm{hPa}(\sim 75 \mathrm{~km})$ on 18 January 2005 (after SPE) minus those on 15 January 2005 (before SPE). For added clarity, the results from the WACCM3 simulations are only shown from $44-90^{\circ} \mathrm{N}$. The MLS averaging kernel (AK) was used to sample the WACCM3 results. The polar cap edge $\left(60^{\circ}\right.$ geomagnetic latitude) is indicated by the white circle.

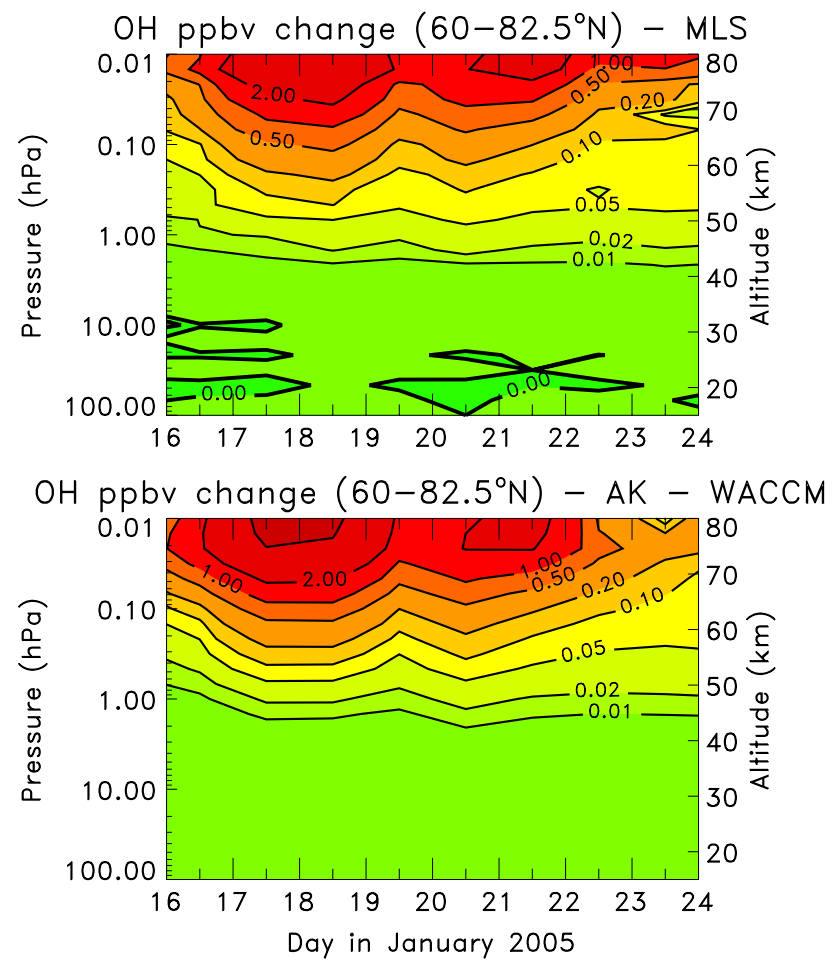

Fig. 5. Daily averaged OH changes from Aura MLS measurements (top) and WACCM3 B average predictions (bottom) for the 60$82.5^{\circ} \mathrm{N}$ band. An average observed (predicted) $\mathrm{OH}$ profile for the period 1-14 January 2005 was subtracted from the observed (predicted) $\mathrm{OH}$ values for the plotted days (16-23 January 2005). The contour intervals for the $\mathrm{OH}$ differences are $0.0,0.01,0.02,0.05$, $0.1,0.2,0.5,1,2$, and 5 ppbv. The MLS averaging kernel (AK) was used to sample the WACCM3 results. 

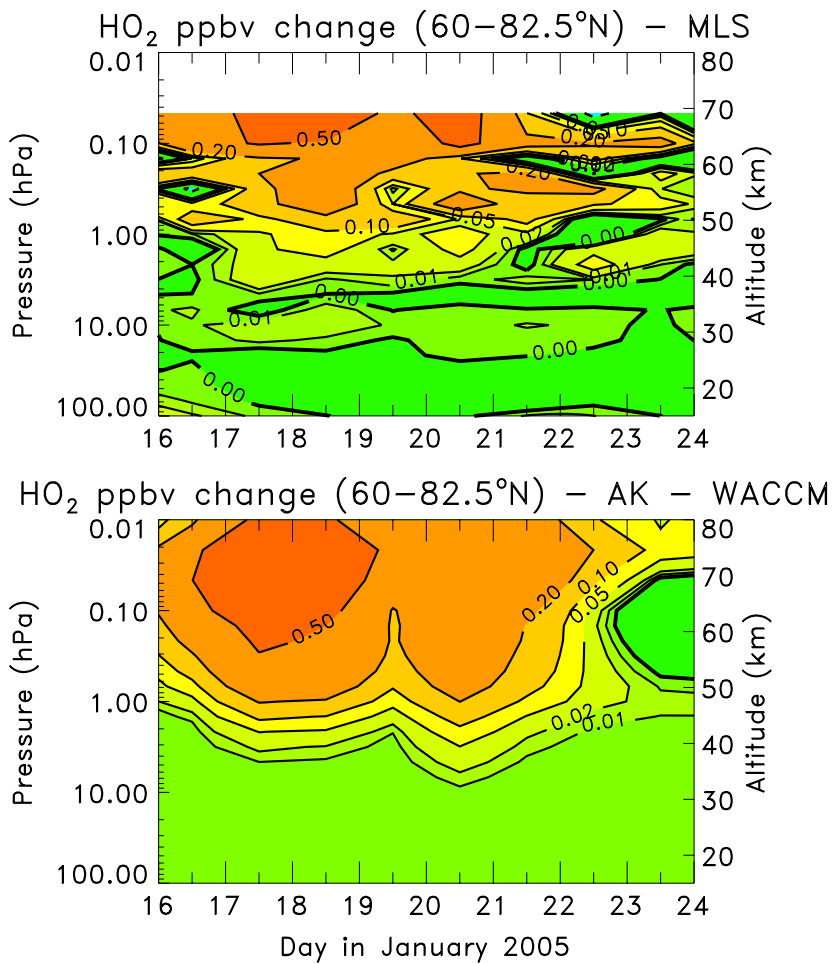

Fig. 6. Daily averaged $\mathrm{HO}_{2}$ changes from Aura MLS measurements (top) and WACCM3 B average predictions (bottom) for the $60-82.5^{\circ} \mathrm{N}$ band. An average observed (predicted) $\mathrm{HO}_{2}$ profile for the period 1-14 January 2005 was subtracted from the observed (predicted) $\mathrm{HO}_{2}$ values for the plotted days (16-23 January 2005). The contour intervals for the $\mathrm{HO}_{2}$ differences are $-0.1,0.0,0.01$, $0.02,0.05,0.1,0.2$, and 0.5 ppbv. The MLS averaging kernel (AK) was used to sample the WACCM3 results.

\subsubsection{Ozone}

Besides these two $\mathrm{HO}_{\mathrm{x}}$ constituents, MLS also measures ozone. Like Figs. 5 and 6, Fig. 7 was produced by averaging the ozone measurements over the quiet (non-SPE) period 114 January 2005 and subtracting this average from the ozone observations or predictions during 16-23 January 2005. As for $\mathrm{OH}$ and $\mathrm{HO}_{2}$, an average of the WACCM3 B realizations sampled with the MLS AK was used for ozone in Fig. 7.

The SPE-produced $\mathrm{HO}_{\mathrm{x}}$ constituents are relatively shortlived ( $\sim$ days) and lead to the destruction of ozone in the uppermost stratosphere and mesosphere. We have found that the WACCM3-predicted ozone change due to the SPEs for the time period plotted is confined to pressures $<1 \mathrm{hPa}$, similar to previous reported studies (e.g., Seppälä et al., 2006; Verronen et al., 2006; Klekociuk et al., 2007). Ozone decreases $(>40 \%)$ are measured and predicted for the 17-23 January 2005 period at pressures $<0.4 \mathrm{hPa}$. Although there is reasonable agreement between WACCM3 and MLS, the model predictions indicate a slightly deeper penetration of the SPE-caused ozone depletion signal.

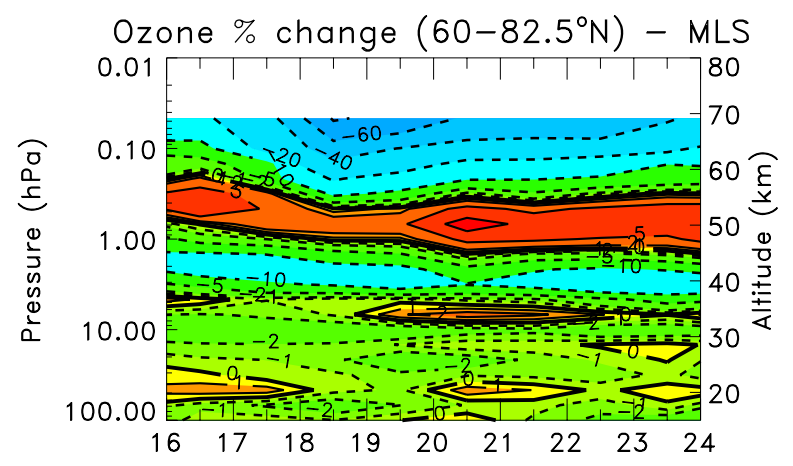

Ozone \% change $\left(60-82.5^{\circ} \mathrm{N}\right)-$ AK - WACCM

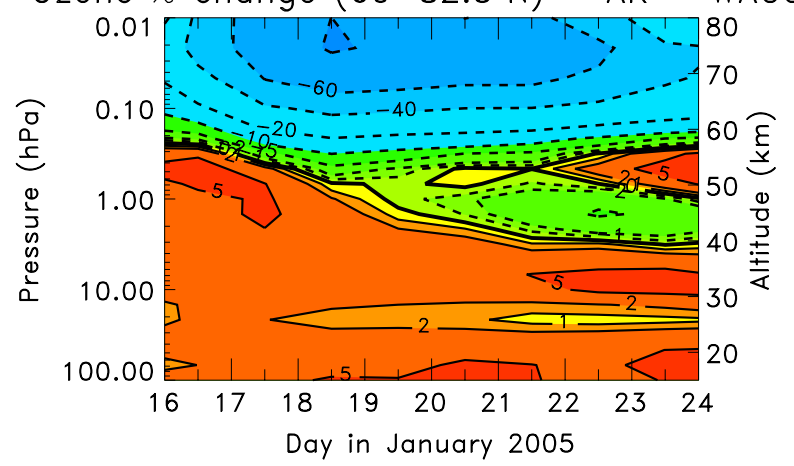

Fig. 7. Daily averaged ozone changes from Aura MLS measurements (top) and WACCM3 B average predictions (bottom) for the $60-82.5^{\circ} \mathrm{N}$ band. An average observed (predicted) ozone profile for the period 1-14 January 2005 was subtracted from the observed (predicted) ozone values for the plotted days (16-23 January 2005). The contour intervals for the ozone differences are $-80,-60,-40$, $-20,-10,-5,-2,-1,0,1,2,5$, and $10 \%$. The MLS averaging kernel (AK) was used to sample the WACCM3 results.

Based on a similar analysis of the WACCM3 A realizations (not shown), the changes in ozone for pressures $>1 \mathrm{hPa}$ in Fig. 7 appear to be caused by seasonal changes at this time of year and are not related to the January 2005 SPEs.

\subsubsection{Hydrogen peroxide $\left(\mathrm{H}_{2} \mathrm{O}_{2}\right)$}

Envisat MIPAS has recently been shown to have the capability of observing hydrogen peroxide $\left(\mathrm{H}_{2} \mathrm{O}_{2}\right)$ (Versick et al., 2009; Versick, 2010) and has provided these measurements in January 2005 during the SPEs. We use here $\mathrm{H}_{2} \mathrm{O}_{2}$ data (version V4O_H2O2_304) retrieved with the MIPAS level 2 processor developed and operated by the Institute of Meteorology and Climate Research (IMK) in Karlsruhe together with the Instituto de Astrofísica de Andalucía (IAA) in Granada. The main source for $\mathrm{H}_{2} \mathrm{O}_{2}$ is the $\mathrm{HO}_{2}$ selfreaction

$\mathrm{HO}_{2}+\mathrm{HO}_{2} \rightarrow \mathrm{H}_{2} \mathrm{O}_{2}+\mathrm{O}_{2}$

with a smaller contribution from the three-body reaction

$\mathrm{OH}+\mathrm{OH}+\mathrm{M} \rightarrow \mathrm{H}_{2} \mathrm{O}_{2}+\mathrm{M}$. 
Thus, production of $\mathrm{OH}$ and $\mathrm{HO}_{2}$ by the SPEs leads very rapidly to the production of $\mathrm{H}_{2} \mathrm{O}_{2}$. Figure 8 (top) shows the polar $\left(60-82.5^{\circ} \mathrm{N}\right)$ MIPAS observed 24-h average $\mathrm{H}_{2} \mathrm{O}_{2}$ for three days (16-18 January 2005) throughout most of the stratosphere and into the lowermost mesosphere. $\mathrm{H}_{2} \mathrm{O}_{2}$ changes during the three days of the first January 2005 SPE (see Sect. 2) are minor at pressure levels greater than $30 \mathrm{hPa}$. At pressure levels less than $30 \mathrm{hPa}, \mathrm{H}_{2} \mathrm{O}_{2}$ is measured to increase during these three days with the largest increases in the lowermost mesosphere $(\sim 60 \mathrm{pptv})$.

Figure 8 (middle) shows the polar $\left(60-82.5^{\circ} \mathrm{N}\right)$ WACCM3 predicted 24-h average $\mathrm{H}_{2} \mathrm{O}_{2}$ for the same three days using an average of the $\mathrm{B}$ realizations. Generally, the modeled amounts of $\mathrm{H}_{2} \mathrm{O}_{2}$ are substantially more than the measured values throughout the plotted domain. $\mathrm{H}_{2} \mathrm{O}_{2}$ is predicted to increase $180 \mathrm{pptv}(\sim 130 \mathrm{pptv}$ to $\sim 310 \mathrm{pptv})$ in the lowermost mesosphere, about a factor of three larger than observed by MIPAS. Figure 8 (bottom) shows the enhanced $\mathrm{H}_{2} \mathrm{O}_{2}$ due to the SPEs and is the difference between an average of the A realizations and an average of the $\mathrm{B}$ realizations. $\mathrm{H}_{2} \mathrm{O}_{2}$ is predicted to increase at all pressure levels during these three days as a result of the SPEs. For better direct comparisons, the MIPAS AK was applied to the plotted WACCM3 results.

What is the reason behind the measurement and model $\mathrm{H}_{2} \mathrm{O}_{2}$ differences? Since the $\mathrm{OH}$ and $\mathrm{HO}_{2}$ predictions are higher than the MLS measurements, it does follow that $\mathrm{H}_{2} \mathrm{O}_{2}$ would likely be overestimated, given the major production reactions (Eqs. 1 and 2). The major loss of $\mathrm{H}_{2} \mathrm{O}_{2}$ during daylight is through photolysis

$$
\mathrm{H}_{2} \mathrm{O}_{2}+h v \rightarrow \mathrm{OH}+\mathrm{OH} \text {. }
$$

During nighttime the reaction

$\mathrm{H}_{2} \mathrm{O}_{2}+\mathrm{OH} \rightarrow \mathrm{H}_{2} \mathrm{O}+\mathrm{HO}_{2}$

is the major loss process for $\mathrm{H}_{2} \mathrm{O}_{2}$. Reaction (4) is especially important in the northern polar latitudes in January, thus is most significant for this study. The $\mathrm{HO}_{\mathrm{x}}$ production from SPEs is in the form of $\mathrm{OH}$ and $\mathrm{H}$ (Solomon et al., 1981). These constituents can very rapidly lead to $\mathrm{HO}_{2}$ production through

$\mathrm{OH}+\mathrm{O}_{3} \rightarrow \mathrm{HO}_{2}+\mathrm{O}_{2}$

and

$\mathrm{H}+\mathrm{O}_{2}+\mathrm{M} \rightarrow \mathrm{HO}_{2}+\mathrm{M}$.

The $\mathrm{HO}_{\mathrm{x}}$ constituents are primarily lost through reactions

$\mathrm{OH}+\mathrm{HO}_{2} \rightarrow \mathrm{H}_{2} \mathrm{O}+\mathrm{O}_{2}$

and

$\mathrm{H}+\mathrm{HO}_{2} \rightarrow \mathrm{H}_{2} \mathrm{O}+\mathrm{O}$

or

$\mathrm{H}+\mathrm{HO}_{2} \rightarrow \mathrm{H}_{2}+\mathrm{O}_{2}$.
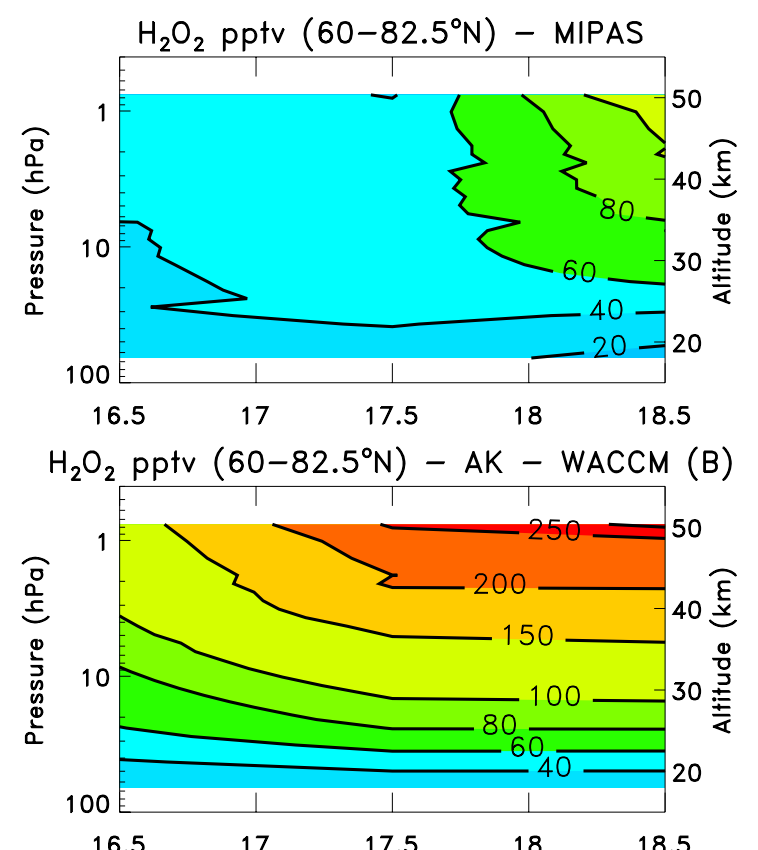

$\mathrm{H}_{2} \mathrm{O}_{2}$ pptv diff. $\left(60-82.5^{\circ} \mathrm{N}\right)-A K-$ WACCM (B-A)

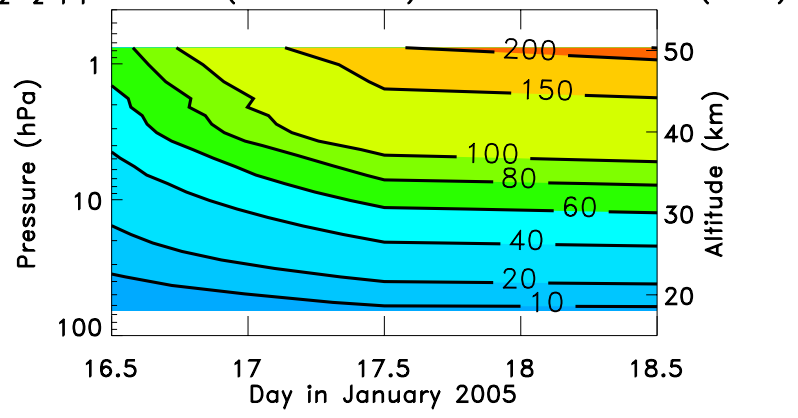

Fig. 8. Daily averaged hydrogen peroxide $\left(\mathrm{H}_{2} \mathrm{O}_{2}\right)$ : Envisat MIPAS measurements (top) and WACCM3 predictions (middle, bottom) for three days, $16-18$ January 2005 , in the $60-82.5^{\circ} \mathrm{N}$ band. The WACCM3 results are from the B average (middle) and a difference between the B average and A average (bottom). The MIPAS averaging kernel (AK) was used to sample the WACCM3 results. The contour intervals are 10, 20, 40, 60, 80, 100, 150, 200, 250, and 300 pptv.

Other reactions, besides Reaction (1) through Reaction (9), are important as well and involve $\mathrm{HO}_{\mathrm{x}}$ species with other atmospheric constituents. All the neutral constituent photochemical reaction rates and photodissociation cross sections are taken from Sander et al. (2006). It is unclear which reaction (or reactions) may need to be modified to rectify the differences between MIPAS and WACCM3 $\mathrm{H}_{2} \mathrm{O}_{2}$. These measurement/model disagreements may be related to the difficulties in simulating $\mathrm{OH}$ and $\mathrm{HO}_{2}$ (e.g., see Canty et al., 2006) and require further study. 


\subsection{Medium-term influences}

SPE-produced $\mathrm{NO}_{\mathrm{x}}$ constituents have longer lifetimes than $\mathrm{HO}_{\mathrm{x}}$ constituents (e.g., Jackman et al., 2008) and can cause atmospheric changes for several weeks or longer following such events. López-Puertas et al. (2005a) has shown large Envisat MIPAS $\mathrm{NO}_{\mathrm{x}}$ enhancements caused by the OctoberNovember 2003 SPEs as well as associated ozone depletion over a two and a half week period. The proton flux during the January 2005 SPEs was not quite as significant as the proton flux during the October-November 2003 SPEs, however, the SPE-induced $\mathrm{NO}_{\mathrm{x}}$ change did occur in the middle of the $\mathrm{NH}$ winter when the impact can be enhanced through a longer lifetime and downward transport (Jackman et al., 2000). We focus on the Northern Hemisphere as any $\mathrm{NO}_{\mathrm{x}}$ signal is most likely to last longer in the darker hemisphere (e.g., Jackman et al., 2008). Quantifying the influence of the $\mathrm{NO}_{\mathrm{x}}$ produced by the January 2005 SPEs is one of the main objectives of this paper.

\subsubsection{Nitrogen dioxide $\left(\mathrm{NO}_{2}\right)$}

Envisat MIPAS provided measurements for some days during the month of January 2005. In particular, we show the four-day average (10-13 January 2005) MIPAS $\mathrm{NO}_{2}$ measurements (IMK/IAA data version V4O_NO2_501) in Fig. 9 (top) before any major SPE disturbance. Although the measured $\mathrm{NO}_{2}$ amounts are at modest levels $(\sim 4-10 \mathrm{ppbv})$ in the middle latitudes $\left(40-60^{\circ} \mathrm{N}\right)$, the observed polar middle mesosphere $\mathrm{NO}_{2}$ can be quite substantial, reaching peak amounts of about $120 \mathrm{ppbv}$ near $70 \mathrm{~km}(\sim 0.03 \mathrm{hPa})$ at the highest northern latitudes.

WACCM3 predictions of $\mathrm{NO}_{2}$ for the same time period are given in Fig. 9 (bottom). The model results do show relatively modest levels $(\sim 1-10 \mathrm{ppbv})$ in the middle latitudes, fairly similar to MIPAS observations. However, WACCM3 only shows peak values $<15 \mathrm{ppbv}$ near $70 \mathrm{~km}(\sim 0.03 \mathrm{hPa})$ at the highest northern latitudes, very different from MIPAS measurements. It appears that MIPAS measurements are indicative of a very disturbed mesosphere before the SPEs commence on 16 January. Seppälä et al. (2007) likewise showed high $\mathrm{NO}_{2}$ mixing ratios ( $>30 \mathrm{ppbv}$ ) in the Northern Hemisphere polar lower mesosphere in early January 2005, measured by the GOMOS instrument.

We used our WACCM3 simulations to compute the $\mathrm{NO}_{2}$ change over the 16-23 January 2005 period in Fig. 10. This $\mathrm{NO}_{2}$ change was computed by subtracting the fourday average (10-13 January 2005) values from the 16-23 January predictions using an average of the $\mathrm{B}$ realizations. The results pertain to the average in the latitude band from $70^{\circ}-90^{\circ} \mathrm{N}$. Nitrogen dioxide enhancements over $30 \mathrm{ppbv}$ are computed in the $60-70 \mathrm{~km}(0.2-0.03 \mathrm{hPa})$ altitude region for 18-20 January 2005.

The MIPAS measurements are not shown over the 1623 January 2005, period due to its limited coverage as the

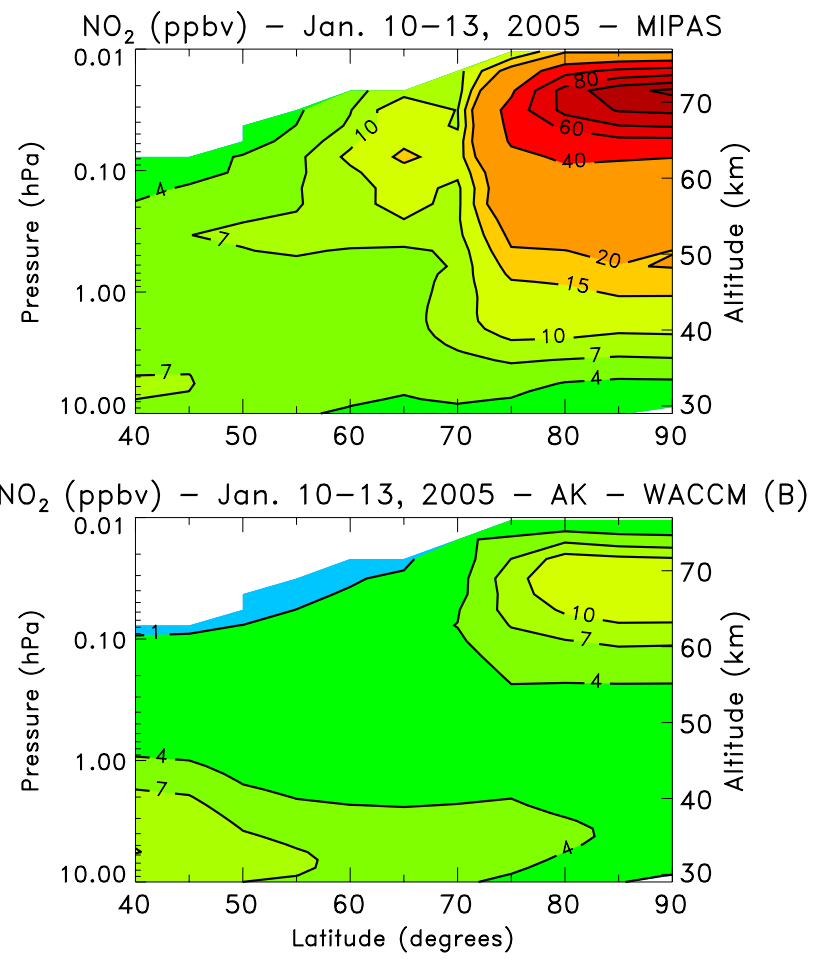

Fig. 9. Envisat MIPAS $\mathrm{NO}_{2}$ measurements (top) and WACCM3 B average (bottom) for the four-day (10-13 January 2005) average in the Northern Hemisphere. The MIPAS averaging kernel (AK) was used to sample the WACCM3 results. The contour intervals are 1, $4,7,10,15,20,40,60,80,100$, and $120 \mathrm{ppbv}$.

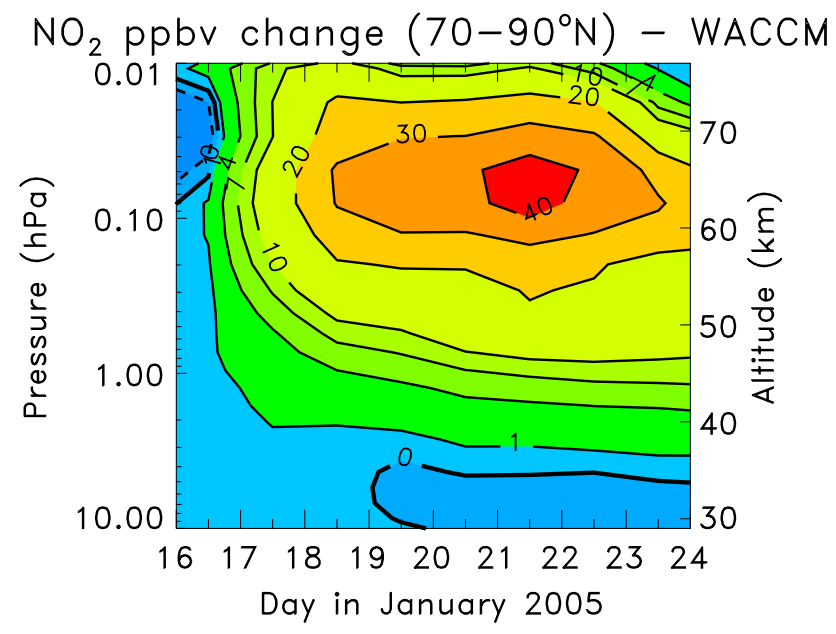

Fig. 10. Daily averaged WACCM3 B average of $\mathrm{NO}_{2}$ change from the four-day (10-13 January 2005) mean for the $70^{\circ}-90^{\circ} \mathrm{N}$ band. The contour intervals are $-1,0,1,4,7,10,20,30$, and $40 \mathrm{ppbv}$.

instrument was measuring in its upper troposphere/lower stratosphere mode with an uppermost temperature retrieval of just $50 \mathrm{~km}$. The temperature above $50 \mathrm{~km}$ was not measured and the assumed temperature was too high in this 
region and greatly impacted the $\mathrm{NO}_{2}$. The TIMED Sounding of the Atmosphere using Broadband Emission Radiometry (SABER) instrument took measurements during this time period and showed that the assumed MIPAS temperatures were about $10-12 \mathrm{~K}$ too warm in the $50-60 \mathrm{~km}$ region. Some preliminary computations with temperatures more similar to SABER (i.e., decreased by $10-12 \mathrm{~K}$ ) have resulted in enhanced MIPAS $\mathrm{NO}_{2}$ values during the first SPE period (1618 January 2005) of about 30 ppbv over the 10-13 January levels. Thus, even though the MIPAS $\mathrm{NO}_{2}$ observations before the SPEs are very different, the deduced MIPAS $\mathrm{NO}_{2}$ increases as a result of the first SPE are fairly similar to the WACCM3 predictions.

\subsubsection{Nitric acid $\left(\mathrm{HNO}_{3}\right)$}

The SPE-caused impact on $\mathrm{HNO}_{3}$ has been discussed before in relation to the October-November 2003 SPEs (Orsolini et al., 2005; López-Puertas et al., 2005b; Jackman et al., 2008; Verronen et al., 2008). Jackman et al. (2008) showed Envisat MIPAS measured $\mathrm{HNO}_{3}$ enhancements of over 2 ppbv near $1 \mathrm{hPa}$ as a result of the late October 2003 SPE, however, the WACCM3 simulations predicted a smaller maximum enhancement of 0.8 ppbv near $1 \mathrm{hPa}$.

Klekociuk et al. (2007) demonstrated $\mathrm{HNO}_{3}$ enhancements in Aura MLS measurements as well as global model computations as a result of the January 2005 SPEs. We have analyzed MLS $\mathrm{HNO}_{3}$ measurements in a similar manner to Klekociuk et al. (2007) and show the results in Fig. 11 (top). Here, an average MLS $\mathrm{HNO}_{3}$ for the period 1-14 January 2005, before the first SPE, was subtracted from the MLS $\mathrm{HNO}_{3}$ for $16-29$ January 2005 in the $60-82.5^{\circ} \mathrm{N}$ band. Envisat MIPAS $\mathrm{HNO}_{3}$ measurements are also available in January 2005, but only for a limited number of days (i.e., 10-13, 16-18, 27-28 January). Because of this limited dataset, the four-day average of the MIPAS measurements before the first SPE (i.e., 10-13 January 2005) was subtracted from the 1618 and 27-28 January 2005 values (IMK/IAA data version V4O_HNO3_201); this difference is given in Fig. 11 (middle). The WACCM3 results are presented in Fig. 11 (bottom), where a $\mathrm{HNO}_{3}$ average of the $\mathrm{B}$ realizations for the period 114 January 2005 before the first SPE was subtracted from the modeled $\mathrm{HNO}_{3}$ for $16-29$ January 2005 in the $60^{\circ}-82.5^{\circ} \mathrm{N}$ band.

The MLS $\mathrm{HNO}_{3}$ measurements indicated two enhanced regions (3-9 and 20-40 hPa) during the 16-25 January 2005 period (also, see Klekociuk et al., 2007) with a region of decreased $\mathrm{HNO}_{3}$ in between. Also, MLS shows decreased $\mathrm{HNO}_{3}$ between 40 and $100 \mathrm{hPa}$. The MIPAS $\mathrm{HNO}_{3}$ observations show similarities to the MLS data on 27-28 January for pressure levels less than $9 \mathrm{hPa}$ and more than $15 \mathrm{hPa}$, however, there is not an indication of the region of decreased $\mathrm{HNO}_{3}$ between 9 and $15 \mathrm{hPa}$. The WACCM3 predicted $\mathrm{HNO}_{3}$ change shows decreases between about 4 and $50 \mathrm{hPa}$ during 16-23 January 2005, with a slight increase at pres-
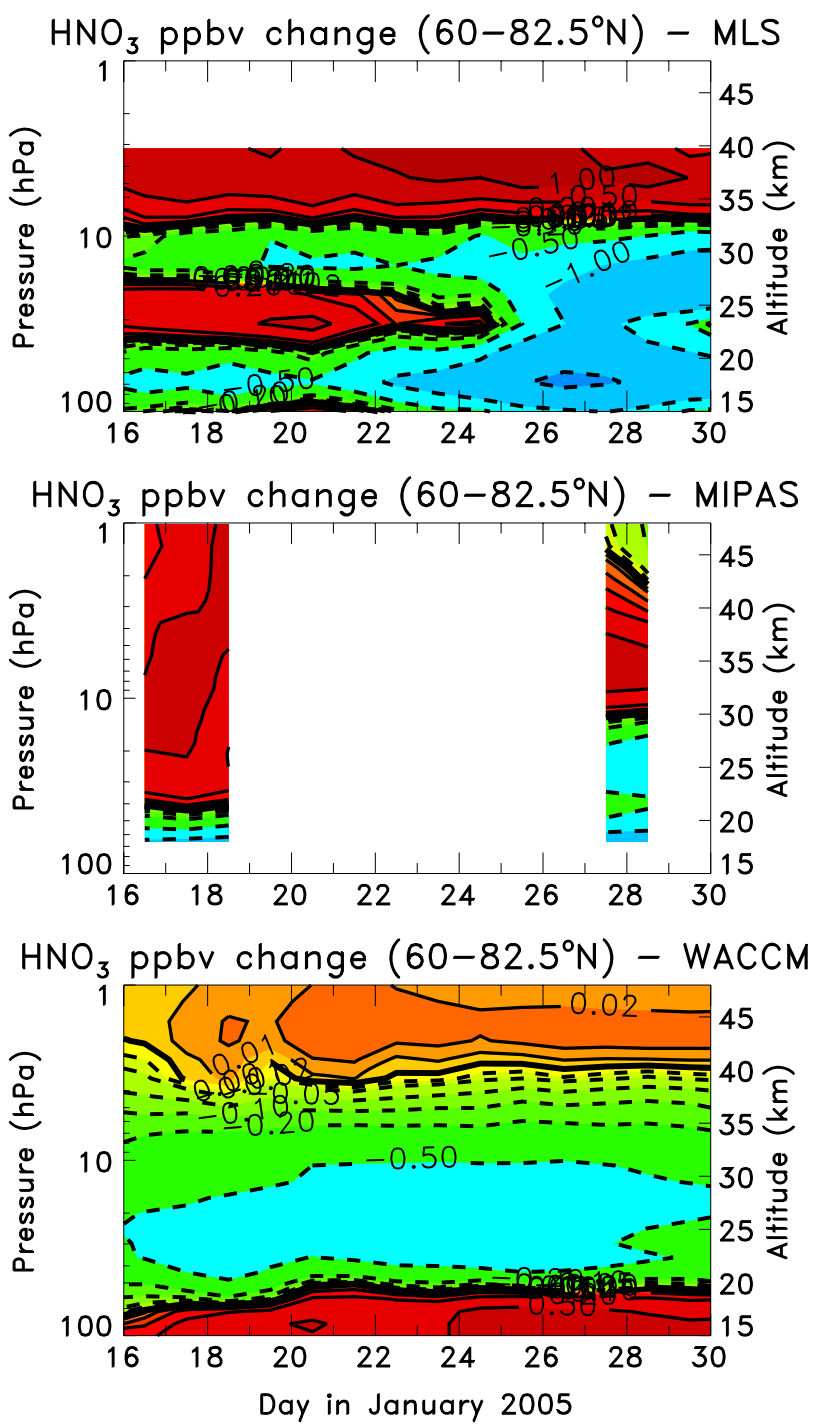

Fig. 11. Daily averaged nitric acid $\left(\mathrm{HNO}_{3}\right)$ change: Aura MLS measurements (top), Envisat MIPAS measurements (middle), and WACCM3 B average (bottom) for 16-29 January 2005 in the $60^{\circ}-$ $82.5^{\circ} \mathrm{N}$ band. A mean $\mathrm{HNO}_{3}$ for the period 1-14 January 2005 was subtracted from the Aura MLS observed and WACCM3 B average predicted values for the plotted days. Envisat MIPAS measurements were only available for 10-13 January 2005, and the average of these four days was subtracted from the 16-18 and 27-28 January 2005 values. The contour intervals are $-2,-1,-0.5,-0.2,-0.1$, $-0.05,-0.02,-0.01,0,0.01,0.02,0.05,0.1,0.2,0.5$, and $1 \mathrm{ppbv}$.

sures less than $4 \mathrm{hPa}$. An average of the WACCM3 A realizations, which is not shown, gives nearly the same results as those predicted from an average of the WACCM3 B realizations, the only difference being the small SPE-caused 0.020.04 ppbv enhanced $\mathrm{HNO}_{3}$ region near $3 \mathrm{hPa}$ over most of the time period. Since WACCM3 results were compared with both MLS and MIPAS observations, neither instrument array of AKs were used to process the WACCM3 output. These 
model/measurement comparisons leave us with the dilemma found in Jackman et al. (2008) whereby large increases in observed $\mathrm{HNO}_{3}$ temporally connected to SPEs could not be properly simulated.

The creation of $\mathrm{HNO}_{3}$ through the ion-ion recombination between $\mathrm{H}^{+}$and $\mathrm{NO}_{3}{ }^{-}$cluster ions was simulated during another solar proton event period, the Halloween storm episode in October-November 2003, with the use of the Sodankylä Ion and Neutral Chemistry model in Verronen et al. (2008). They showed that the $\mathrm{HNO}_{3}$ production above $35 \mathrm{~km}$ as a result of those large events could account for the extra $\mathrm{HNO}_{3}$ observed by MIPAS in October/November 2003. It is likely that this ion chemistry, currently not included in WACCM3, could also explain the MLS and MIPAS observed additional $0.5-1$ ppbv $\mathrm{HNO}_{3}$ above $35 \mathrm{~km}$ (pressures $<7 \mathrm{hPa}$ ) seen in Fig. 11.

\subsubsection{Nitrogen oxides, $\mathrm{NO}_{\mathrm{x}}\left(\mathrm{NO}+\mathrm{NO}_{2}\right)$}

ACE-FTS (hereinafter referred to as ACE) (Bernath et al., 2005) provided measurements during all of the SPE period. ACE measured both $\mathrm{NO}$ and $\mathrm{NO}_{2}$ (e.g., see Rinsland et al., 2005), and thus supplied $\mathrm{NO}_{\mathrm{x}}\left(\mathrm{NO}+\mathrm{NO}_{2}\right)$ measurements at fairly high northern latitudes for 1-31 January 2005. These ACE observations are given in Fig. 12a and were taken in the latitude range from $\sim 57-66^{\circ} \mathrm{N}$ (see Fig. 12, top). Large amounts of $\mathrm{NO}_{\mathrm{x}}$ are observed at pressures $<0.01 \mathrm{hPa}$ with evidence of some downward transport over this time period, especially in the latter half of the month. We focus on pressures $>0.01 \mathrm{hPa}$, where there is an indication of a large perturbation around 16 January. After that date the contour levels $20,50,100$, and 200 ppbv show substantially more $\mathrm{NO}_{\mathrm{x}}$ measured in the pressure range 0.02 to about $0.4 \mathrm{hPa}(\sim 55-$ $75 \mathrm{~km}$ ).

The ACE measurements (Fig. 12a) are compared with similar plots from our WACCM3 simulations in Fig. 12b, c. The WACCM3 results are taken from the model predictions for the $60-66^{\circ} \mathrm{N}$ latitude bins, approximately the latitude range for the ACE Northern Hemisphere measurements after 6 January 2005. There are no AKs for the ACE instrument because optimal estimation is not used in the ACE retrievals, thus the unprocessed WACCM3 output is used for these comparisons. Figure $12 \mathrm{c}$ shows $\mathrm{WACCM} 3 \mathrm{NO}_{\mathrm{x}}$ predictions from an average of the A realizations. This plot does not indicate much of a change in $\mathrm{NO}_{\mathrm{x}}$ over the month. In fact, the predicted $\mathrm{NO}_{\mathrm{x}}$ in the pressure range 0.02 to $0.4 \mathrm{hPa}$ after 16 January appears to show a slight decrease at most levels. Figure $12 \mathrm{~b}$ shows WACCM3 $\mathrm{NO}_{\mathrm{x}}$ predictions from an average of the $\mathrm{B}$ realizations. These model predictions show a dramatic change after 16 January with large $\mathrm{NO}_{\mathrm{x}}$ increases due to the SPEs, as indicated by changes in the slopes of contour levels 10, 20, 50, and 100 ppbv.

The $\mathrm{NO}_{\mathrm{x}}$ variations over the three month time period (1 January-31 March 2005) are given in Fig. 13. Again, ACE measurements are shown in the top plot. There is a change in

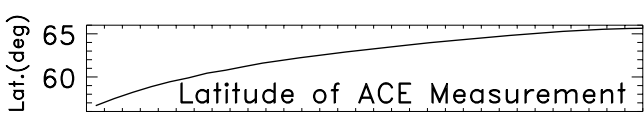

(a) $\mathrm{NO}_{x}$ ppbv (Northern Hem.) - ACE
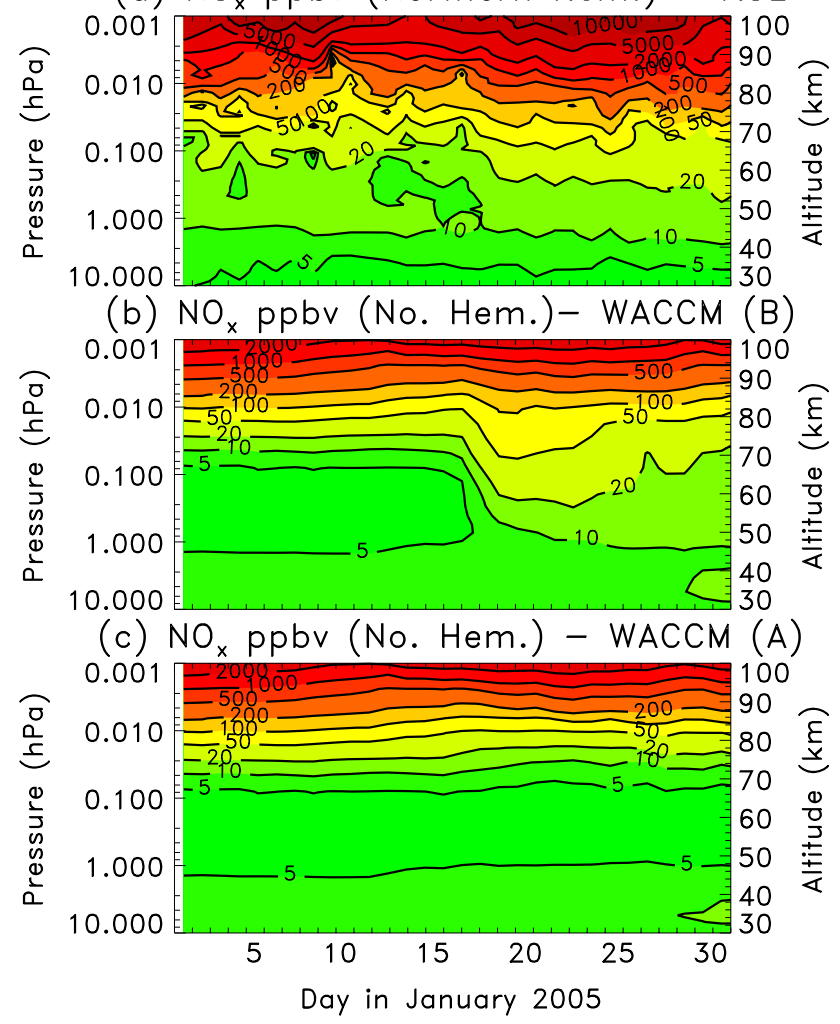

Fig. 12. Daily averaged $\mathrm{NO}_{\mathrm{x}}$ measurements (a) and predictions (b, c) for 1-31 January 2005 in the high latitude Northern Hemisphere (see Sect. 5.2.3). The $\mathrm{ACE} \mathrm{NO}_{\mathrm{x}}$ measurements are given in (a). The WACCM3 $\mathrm{NO}_{\mathrm{x}}$ predictions are from an average of the $\mathrm{B}$ realizations (b) and the A realizations (c). The contour intervals for $\mathrm{NO}_{\mathrm{x}}$ are 1, 2, 5, 10, 20, 50, 100, 200, 500, 1000, 2000, 5000, and 10000 ppbv. The latitudes of ACE measurements are given in the top plot.

the slopes of the $\mathrm{NO}_{\mathrm{x}}$ contours after Day of Year (DoY) 32, when $\mathrm{NO}_{\mathrm{x}}$ amounts tend to decrease with time at virtually all levels above $\sim 1 \mathrm{hPa}$. ACE observes at latitudes greater than $60^{\circ} \mathrm{N}$ up through DoY 83 (24 March), thus this $\mathrm{NO}_{\mathrm{x}}$ change is probably related more to a seasonal effect, not related to the SPEs, than to the variation in ACE measurement latitudes during the season. After DoY 83, the latitude observed by ACE varies rapidly from $60^{\circ} \mathrm{N}$ to $41^{\circ} \mathrm{N}$ by DoY 90. These rapid changes in observed latitude help to explain the fast decrease of observed $\mathrm{NO}_{\mathrm{x}}$ in the last week plotted in Fig. 13 (top). Downward transport of thermospheric $\mathrm{NO}_{\mathrm{x}}$ in the winter and early spring, not related to the SPEs, is much larger at polar latitudes than middle latitudes (e.g., Randall et al., 2005, 2006).

MIPAS also measured $\mathrm{NO}_{\mathrm{x}}$ for 16 days (e.g., DoYs $27-28$, $38,44-46,48-49,52-53,61-62,67-68$, and $80-81)$ in this 


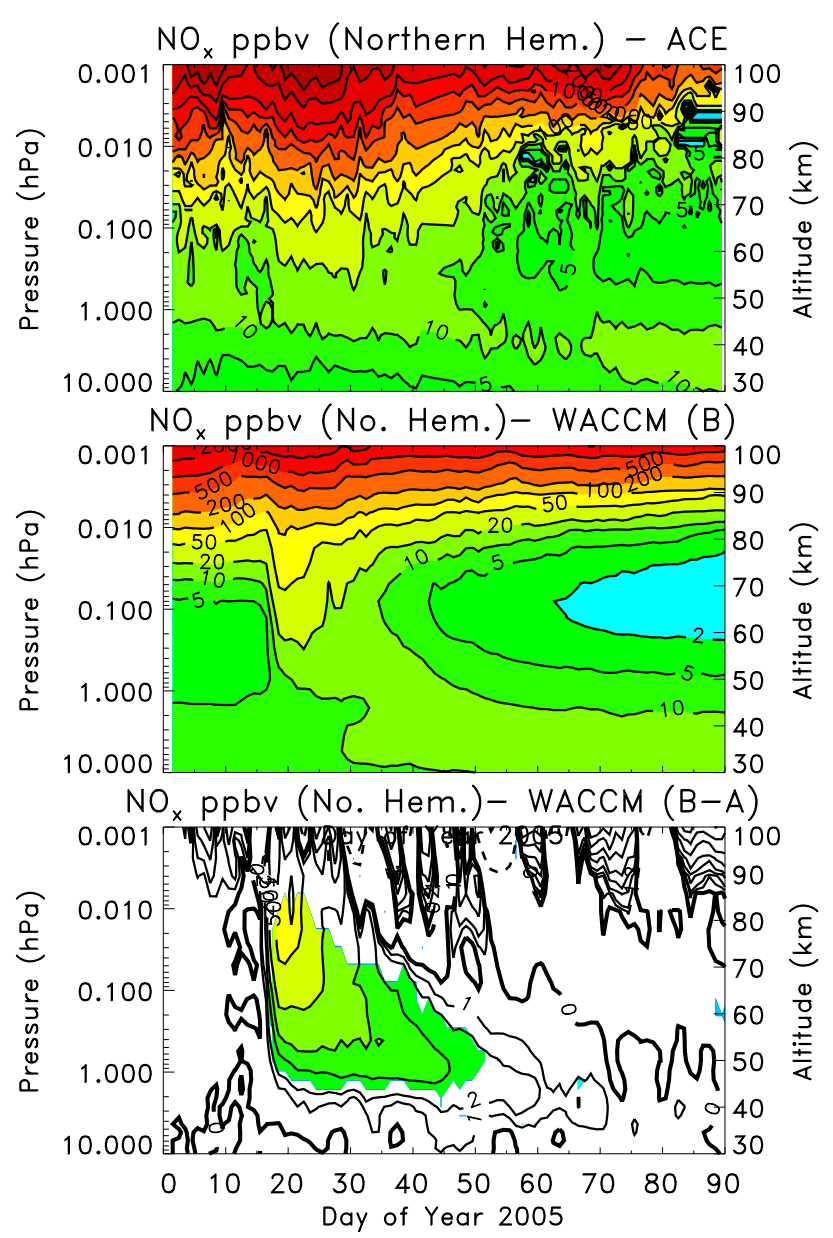

Fig. 13. Daily averaged SCISAT-1 ACE measurements (top) and WACCM3 predictions (middle, bottom) for $\mathrm{NO}_{\mathrm{x}}$ during the first 90 days of 2005 (1 January-31 March) for the high latitude Northern Hemisphere. The WACCM3 $\mathrm{NO}_{\mathrm{x}}$ predictions (middle) are from an average of the $\mathrm{B}$ realizations and the WACCM3 $\mathrm{NO}_{\mathrm{x}}$ predictions (bottom) show the $\mathrm{NO}_{\mathrm{x}}$ enhancement due to the SPEs (an average of the $\mathrm{B}$ realizations minus an average of the A realizations). The colored regions indicate $95 \%$ statistical significance with the use of Student's $t$ test. The contour intervals are 1, 2, 5, 10, 20, 50, 100, 200, 500, 1000, 2000, 5000, and 10000 ppbv.

period over a limited altitude range on most days. We have found that, generally, MIPAS observations are in reasonable agreement with ACE (not shown).

Figure 13 (middle) shows WACCM3 $\mathrm{NO}_{\mathrm{x}}$ predictions $\left(60-66^{\circ} \mathrm{N}\right)$ from an average of the $\mathrm{B}$ simulations (SPEsonly), essentially an extension of Fig. 12b for another 59 days. There are many similarities between these model computations and the ACE measurements. The change in slope of the contour levels indicating a decrease in $\mathrm{NO}_{\mathrm{x}}$ at virtually all levels above $\sim 1 \mathrm{hPa}$ occurs in the model simulations at about DoY 25 (rather than the DoY 32 in the ACE measurements), however, qualitatively the model results and ACE measurements are in reasonable agreement.
We are able to compute the quantitative $\mathrm{NO}_{\mathrm{x}}$ enhancement due to the SPEs by subtracting an average of the A realizations from the average of the $\mathrm{B}$ realizations. These results are given in Fig. 13 (bottom), where the colored regions indicate $95 \%$ statistical significance with the use of Student's $t$ test. The SPEs caused $\mathrm{NO}_{\mathrm{x}}$ increases $>50 \mathrm{ppbv}$ in the middle to upper mesosphere. These $\mathrm{NO}_{\mathrm{x}}$ enhancements diminished over time to be less than $5 \mathrm{ppbv}$ and no longer statistically significant by DoY 50. Thus, the SPE-caused $\mathrm{NO}_{\mathrm{x}}$ increases from the January 2005 SPEs lasted for about one month past the beginning of the events.

\subsubsection{Ozone and temperature}

We computed the ozone change due to SPEs over the 1 January-31 March 2005 period by comparing the average of the $B$ realizations relative to an average of the A realizations. The large ozone decreases shown in Fig. 7 extended another two days (through DoY 25), however, statistically significant (to $95 \%$ ) NH polar mesospheric ozone loss computed with Student's $t$ test was evident only from DoY 17-23. Ozone depletion less than $5 \%$ due to the SPEs was calculated for a couple of weeks past the end of January. These results are consistent with the SPE-induced short-lived $\mathrm{HO}_{\mathrm{x}}$ enhancements causing most of the mesospheric ozone loss.

We also computed the temperature change due to SPEs over the 1 January-31 March 2005 period by comparing the average of the $\mathrm{B}$ realizations relative to an average of the A realizations. These computed temperature changes were less than $3 \mathrm{~K}$ during the time period of the large computed ozone losses (DoY 17-23) and were not statistically significant. Such small temperature changes are consistent with Jackman et al. (2007) and are not surprising in the limited sunlit polar region $(\mathrm{NH})$ where less ozone heating occurs.

\section{Influences of the 20 January 2005 GLE}

As discussed previously (Sects. 1 and 2), a very large GLE occurred on 20 January 2005, during the SPE period. Although the flux of very energetic protons was extremely high, the duration of this intense flux was fairly short (less than about $8 \mathrm{~h}$ for the highest energy protons, see NOAA GOES11 data). The most substantial increase in the high energy protons lasted only about $90 \mathrm{~m}$ (Simnett and Roelof, 2005). Also, these very high energy protons primarily impacted the middle to lower stratosphere (10-100 hPa, see Fig. 2), thus the influence on this lower region of the atmosphere is diluted by the increased number density of molecules (compared to the mesosphere). A daily averaged GLE ionization rate is used for consistency with the other WACCM3 computations.

Since the $\mathrm{NO}_{\mathrm{x}}$ family rapidly converts in the stratosphere to other constituents in the odd nitrogen group $\left(\mathrm{NO}_{\mathrm{y}}=\mathrm{N}\left({ }^{4} \mathrm{~S}\right)+\mathrm{N}\left({ }^{2} \mathrm{D}\right)+\mathrm{NO}+\mathrm{NO}_{2}+\mathrm{NO}_{3}+2 \mathrm{~N}_{2} \mathrm{O}_{5}+\right.$ $\mathrm{HNO}_{3}+\mathrm{HO}_{2} \mathrm{NO}_{2}+\mathrm{ClONO}_{2}+\mathrm{BrONO}_{2}$ ), it is appropriate 
to concentrate on the $\mathrm{NO}_{\mathrm{y}}$ impact due to the GLE. We have computed the percentage change of $\mathrm{NO}_{\mathrm{y}}$ at polar northern latitudes $\left(60-90^{\circ} \mathrm{N}\right)$ over the 19-23 January 2005 period by subtracting an average of the $\mathrm{C}$ realizations from an average of the B realizations and present these results in Fig. 14. As a result of the GLE, odd nitrogen is calculated to be enhanced by a maximum of about $0.09 \%$, a very small increase. Ozone changes appear to be connected to these $\mathrm{NO}_{\mathrm{y}}$ enhancements and show a maximum of about a $0.007 \%$ decrease. Although the computed $\mathrm{HO}_{\mathrm{x}}$ changes due to the GLE are larger ( $>20 \%$ in the $20-100 \mathrm{hPa}$ range), this seemingly significant impact is mainly due to the small amount of ambient $\mathrm{HO}_{\mathrm{x}}$ in the polar very low sun conditions at this time of year. Ambient $\mathrm{HO}_{\mathrm{x}}$ values in the $60-90^{\circ} \mathrm{N}$ region range from $0.002-0.3 \mathrm{pptv}$ at $100 \mathrm{hPa}$ to $1.2-1.9 \mathrm{pptv}$ at $20 \mathrm{hPa}$. The computed $\mathrm{HO}_{\mathrm{x}}$ enhancement is short-lived and is essentially gone within $48 \mathrm{~h}$ due to the short lifetime of the $\mathrm{HO}_{\mathrm{x}}$ constituents.

As an aside, the polar southern latitudes $\left(60-90^{\circ} \mathrm{S}\right)$ were also impacted in a minor way due to this GLE. $\mathrm{NO}_{\mathrm{y}}$ was increased in the lower stratosphere by a maximum of $0.18 \%$ and ozone was decreased by a maximum of $0.05 \%$ when WACCM3 B results were compared with $\mathrm{C}$ results. The southern polar $\mathrm{HO}_{\mathrm{x}}$ was enhanced by a maximum of $2 \%$, but this enhancement was gone within $24 \mathrm{~h}$.

These WACCM3 simulations indicate that inclusion of the GLE on 20 January leads to very small atmospheric constituent perturbations.

\section{Conclusions}

The January 2005 SPEs caused large enhancements in the northern polar mesospheric $\mathrm{HO}_{\mathrm{x}}$ and $\mathrm{NO}_{\mathrm{x}}$ constituents, which were both observed and modeled. Aura MLS observations indicated large mesospheric increases in $\mathrm{OH}$ (up to 4 ppbv) and $\mathrm{HO}_{2}(>0.5 \mathrm{ppbv})$ as a result of the SPEs during the time period $16-21$ January in the $60-85^{\circ} \mathrm{N}$ latitude band. The WACCM3 simulations showed quantitatively similar, although somewhat larger enhancements in $\mathrm{OH}$ and $\mathrm{HO}_{2}$. These large $\mathrm{HO}_{\mathrm{x}}$ enhancements led to considerable MLS-measured and predicted ozone decreases of greater than $40 \%$ throughout most of the northern polar mesosphere during the SPE period. MIPAS measured $\mathrm{H}_{2} \mathrm{O}_{2}$ enhancements through the stratosphere into the lower mesosphere (reaching $\sim 60$ pptv) from 16 January to 18 January. WACCM3 also predicted $\mathrm{H}_{2} \mathrm{O}_{2}$ increases over the same period, however, these predictions were about a factor of three larger than observed.

Nitric acid measured by both MLS and MIPAS increased in the upper stratosphere during 16-23 January when compared with 1-14 January 2005, however, WACCM3 predictions indicated only minor enhancements in the same time period and altitude range. WACCM3 currently lacks ion chemical reactions responsible for the SPE-caused cre-

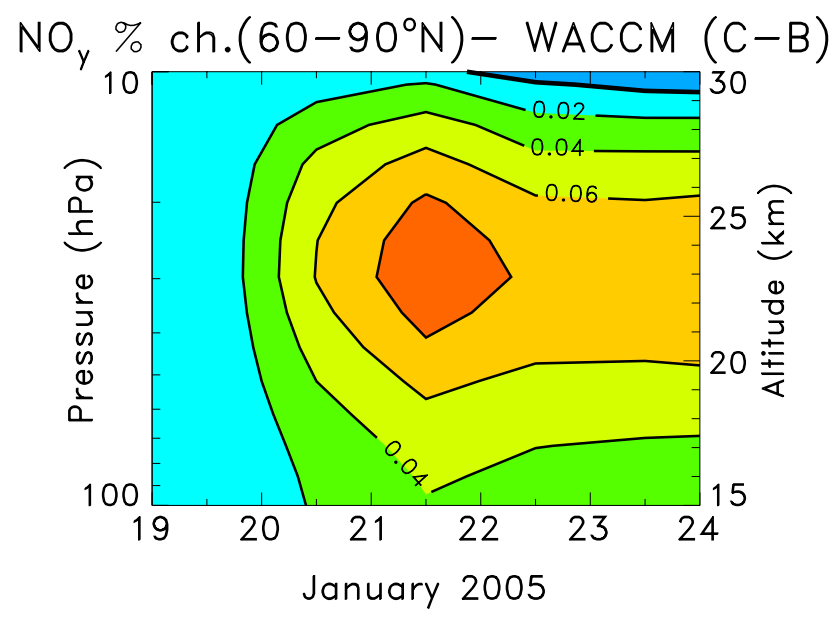

Fig. 14. Daily averaged WACCM3 prediction of the polar Northern Hemisphere $\left(60-90^{\circ} \mathrm{N}\right) \mathrm{NO}_{\mathrm{y}}$ percentage enhancement due to the GLE (the average of the $\mathrm{C}$ realizations minus the average of the $\mathrm{B}$ realizations). The contour intervals are $0.0,0.02,0.04,0.06$, and $0.08 \%$.

ation of $\mathrm{HNO}_{3}$ (Verronen et al., 2008). MIPAS observations showed large enhancements of polar middle mesospheric $\mathrm{NO}_{2}$ before the SPEs, which were likely the result of $\mathrm{NO}_{\mathrm{x}}$ winter descent from higher altitudes (also, see GOMOS measurements in Seppälä et al., 2007). However during the SPEs, WACCM3 simulated a mesospheric $\mathrm{NO}_{2}$ enhancement of greater than $30 \mathrm{ppbv}$ in the $60-70 \mathrm{~km}(0.2-0.03 \mathrm{hPa})$ altitude region for 18-20 January 2005 in the polar Northern Hemisphere, which is in reasonable agreement with inferred MIPAS $\mathrm{NO}_{2}$ increases over the same altitude region. WACCM3 predictions are in reasonable agreement with SCISAT-1 ACE measurements of $\mathrm{NO}_{\mathrm{x}}$ enhancements for the Northern Hemisphere. The observed and predicted enhancements are considerable for the mesosphere and led to statistically significant $\mathrm{NO}_{\mathrm{x}}$ increases in polar northern latitudes for about a month past the SPEs.

We found that protons of energies 300 to $20000 \mathrm{MeV}$, associated with the GLE on 20 January, led to enhanced stratospheric $\mathrm{NO}_{\mathrm{y}}$ of less than $0.1 \%$ and ozone decreases of less than $0.01 \%$ in the northern polar latitudes. Thus, protons with energies less than $300 \mathrm{MeV}$ had a much larger impact on the middle atmosphere in January 2005 than higher energy protons from the GLE.

Acknowledgements. We thank NASA Headquarters Living With a Star Targeted Research and Technology Program and the Aura Science Team Program for support during the time that this manuscript was written. CER was supported by NASA LWS grants NNX08AU44G and NNX06AC05G. We thank Nathaniel Livesey, Shuhui Wang, and Herbert Pickett of the Aura MLS Team for help in utilizing the MLS measurements and application of the MLS averaging kernels to WACCM3 output. We thank Gordon J. Labow (Science Systems and Applications, Inc.) for help with plotting Figs. 3 and 4. We thank the NOAA GOES team for providing the 
solar proton flux data over the Internet. The National Center for Atmospheric Research is sponsored by the National Science Foundation. WACCM3 results presented in this paper were generated using NASA's Columbia supercomputer housed at the NASA Ames Research Center. The ACE mission is supported primarily by the Canadian Space Agency. Some support was also provided by the UK Natural Environment Research Council, NERC. MIPAS work presented in this paper was funded by the project MANOXUVA within the DFG priority project 1176 CAWSES. The IAA team was supported by the Spanish MICINN under project AYA200803498/ESP and EC FEDER funds. MIPAS level-1b data have been provided by ESA.

Edited by: A. J. G. Baumgaertner

\section{References}

Bernath, P. F., McElroy, C. T., Abrams, M. C., Boone, C. D., Butler, M., Camy-Peyret, C., Carleer, M., Clerbaux, C., Coheur, P.F., Colin, R., DeCola, P., DeMaziére, M., Drummond, J. R., Dufour, D., Evans, W. F. J., Fast, H., Fussen, D., Gilbert, K., Jennings, D. E., Llewellyn, E. J., Lowe, R. P., Mahieu, E., McConnell, J. C., McHugh, M., McLeod, S. D., Michaud, R., Midwinter, C., Nassar, R., Nichitiu, F., Nowlan, C., Rinsland, C. P., Rochon, Y. J., Rowlands, N., Semeniuk, K., Simon, P., Skelton, R., Sloan, J. J., Soucy, M.-A., Strong, K., Tremblay, P., Turnbull, D., Walker, K. A., Walkty, I., Wardle, D. A., Wehrle, V., Zander, R., and Zou, J.: Atmospheric Chemistry Experiment (ACE): mission overview, Geophys. Res. Lett., 32, L15S01, doi:10.1029/2005GL022386, 2005.

Canty, T., Pickett, H. M., Salawitch, R. J., Jucks, K. W., Traub, W. A., and Waters, J. W.: Stratospheric and mesospheric $\mathrm{HO}_{\mathrm{X}}$ : results from Aura MLS and FIRS-2, Geophys. Res. Lett., 33, L12802, doi:10.1029/2006GL025964, 2006.

Damiani, A., Storini, M., Laurenza, M., and Rafanelli, C.: Solar particle effects on minor components of the Polar atmosphere, Ann. Geophys., 26, 361-370, doi:10.5194/angeo-26-361-2008, 2008.

Damiani, A., Diego, P., Laurenza, M., Storini, M., and Rafanelli, C.: Ozone variability related to SEP events occurring during solar cycle no. 23, Adv. Space Res., 43, 28-40, 2009.

Damiani, A., Storini, M., Rafanelli, C., and Diego, P.: The hydroxyl radical as an indicator of SEP fluxes in the high-latitude terrestrial atmosphere, Adv. Space Res., 46, 1225-1235, 2010.

Forkman, P., Eriksson, P., Winnberg, A., Garcia, R. R., and Kinnison, D.: Longest continuous ground-based measurements of mesospheric CO, Geophys. Res. Lett., 30, 1532, doi:10.1029/2003GL016931, 2003.

Garcia, R. R., Marsh, D. R., Kinnison, D. E., Boville, B. A., and Sassi, F.: Simulation of secular trends in the middle atmosphere, 1950-2003, J. Geophys. Res., 112, D09301, doi:10.1029/2006JD007485, 2007.

Gopalswamy, N., Xie, H., Yashiro, S., and Usoskin, I.: Coronal mass ejections and ground level enhancements, 29th International Cosmic Ray Conference Pune, India, 1, 101-104, 3-10 August 2005.

Jackman, C. H. and McPeters, R. D.: The response of ozone to solar proton events during solar cycle 21: a theoretical interpretation,
J. Geophys. Res., 90, 7955-7966, 1985.

Jackman, C. H., Frederick, J. E., and Stolarski, R. S.: Production of odd nitrogen in the stratosphere and mesosphere: an intercomparison of source strengths, J. Geophys. Res., 85, 7495-7505, 1980.

Jackman, C. H., Fleming, E. L., and Vitt, F. M.: Influence of extremely large solar proton events in a changing stratosphere, J. Geophys. Res., 105, 11659-11670, 2000.

Jackman, C. H., McPeters, R. D., Labow, G. J., Fleming, E. L., Praderas, C. J., and Russell, J. M.: Northern Hemisphere atmospheric effects due to the July 2000 solar proton event, Geophys. Res. Lett., 28, 2883-2886, 2001.

Jackman, C. H., DeLand, M. T., Labow, G. J., Fleming, E. L., Weisenstein, D. K., Ko, M. K. W., Sinnhuber, M., and Russell, J. M.: Neutral atmospheric influences of the solar proton events in October-November 2003, J. Geophys. Res., 110, A09S27, doi:10.1029/2004JA010888, 2005.

Jackman, C. H., Roble, R. G., and Fleming, E. L.: Mesospheric dynamical changes induced by the solar proton events in October-November 2003, Geophys. Res. Lett., 34, L04812, doi:10.1029/2006GL028328, 2007.

Jackman, C. H., Marsh, D. R., Vitt, F. M., Garcia, R. R., Fleming, E. L., Labow, G. J., Randall, C. E., López-Puertas, M., Funke, B., von Clarmann, T., and Stiller, G. P.: Shortand medium-term atmospheric constituent effects of very large solar proton events, Atmos. Chem. Phys., 8, 765-785, doi:10.5194/acp-8-765-2008, 2008.

Jackman, C. H., Marsh, D. R., Vitt, F. M., Garcia, R. R., Randall, C. E., Fleming, E. L., and Frith, S. M.: Long-term middle atmospheric influence of very large solar proton events, J. Geophys. Res., 114, D11304, doi:10.1029/2008JD011415, 2009.

Kinnison, D. E., Brasseur, G. P., Walters, S., Garcia, R. R., Marsh, D. R., Sassi, F., Harvey, V. L., Randall, C. E., Emmons, L., Lamarque, J. F., Hess, P., Orlando, J. J., Tie, X. X., Randel, W., Pan, L. L., Gettelman, A., Granier, C., Diehl, T., Niemeier, U., and Simmons, A. J.: Sensitivity of chemical tracers to meteorological parameters in the MOZART-3 chemical transport model, J. Geophys. Res., 112, D20302, doi:10.1029/2006JD007879, 2007.

Klekociuk, A. R., Bombardieri, D. J., Duldig, M. L., and Michael, K. J.: Atmospheric chemistry effects of the 20 January 2005 solar proton event, Adv. Geosci., 14, Solar Terrestrial, 305319, 2007.

López-Puertas, M., Funke, B., Gil-López, S., von Clarmann, T., Stiller, G. P., Höpfner, M., Kellmann, S., Fischer, H., and Jackman, C. H.: Observation of $\mathrm{NO}_{\mathrm{X}}$ enhancement and ozone depletion in the Northern and Southern Hemispheres after the OctoberNovember 2003 solar proton events, J. Geophys. Res., 110, A09S43, doi:10.1029/2005JA011050, 2005a.

López-Puertas, M., Funke, B., Gil-López, S., von Clarmann, T., Stiller, G. P., Höpfner, M., Kellmann, S., Mengistu Tsidu, G., Fischer, H., and Jackman, C. H.: $\mathrm{HNO}_{3}$, $\mathrm{N}_{2} \mathrm{O}_{5}$, and $\mathrm{ClONO}_{2}$ enhancements after the October-November 2003 solar proton events, J. Geophys. Res., 110, A09S44, doi:10.1029/2005JA011051, 2005b.

Marsh, D. R., Garcia, R. R., Kinnison, D. E., Boville, B. A., Sassi, F., Solomon, S. C., and Matthes, K.: Modeling the whole atmosphere response to solar cycle changes in radiative and geomagnetic forcing, J. Geophys. Res., 112, D23306, 
doi:10.1029/2006JD008306, 2007.

McPeters, R. D., Jackman, C. H., and Stassinopoulos, E. G.: Observations of ozone depletion associated with solar proton events, J. Geophys. Res., 86, 12071-12081, 1981.

Orsolini, Y. J., Manney, G. L., Santee, M. L., and Randall, C. E.: An upper stratospheric layer of enhanced $\mathrm{HNO}_{3}$ following exceptional solar storms, Geophys. Res. Lett., 32, L12S01, doi:10.1029/2004GL021588, 2005.

Pickett, H. M., Drouin, B. J., Canty, T., Salawitch, R. J., Fuller, R. A., Perun, V. S., Livesey, N. J., Waters, J. W., Stachnik, R. A., Sander, S. P., Traub, W. A., Jucks, K. W., and Minschwaner, K.: Validation of Aura Microwave Limb Sounder $\mathrm{OH}$ and $\mathrm{HO}_{2}$ measurements, J. Geophys. Res. 113, D16S30, doi:10.1029/2007JD008775, 2008.

Porter, H. S., Jackman, C. H., and Green, A. E. S.: Efficiencies for production of atomic nitrogen and oxygen by relativistic proton impact in air, J. Chem. Phys., 65, 154-167, 1976.

Randall, C. E., Harvey, V. L., Manney, G. L., Orsolini, Y., Codrescu, M., Sioris, C., Brohede, S., Haley, C. S., Gordley, L. L., Zawodny, J. M., and Russell, J. M.: Stratospheric effects of energetic particle precipitation in 2003-2004, Geophys. Res. Lett., 32, L05802, doi:10.1029/2004GL022003, 2005.

Randall, C. E., Harvey, V. L., Singleton, C. S., Bernath, P. F., Boone, C. D., and Kozyra, J. U.: Enhanced $\mathrm{NO}_{\mathrm{x}}$ in 2006 linked to strong upper stratospheric Arctic vortex, Geophys. Res. Lett., 33, L18811, doi:10.1029/2006GL027160, 2006.

Richter, J. H. and Garcia, R. R.: On the forcing of the Mesospheric Semi-Annual Oscillation in the Whole Atmosphere Community Climate Model, Geophys. Res. Lett., 33, L01806, doi:10.1029/2005GL024378, 2006.

Rinsland, C. P., Boone, C., Nassar, R., Walker, K., Bernath, P., McConnell, J. C., and Chiou, L.: Atmospheric Chemistry Experiment (ACE) Arctic stratospheric measurements of $\mathrm{NO}_{\mathrm{x}}$ during February and March 2004: Impact of intense solar flares, Geophys. Res. Lett., 32, L16S05, doi:10.1029/2005GL022425, 2005.

Sassi, F., Garcia, R. R., Boville, B. A., and Liu, H.: On temperature inversions and the mesospheric surf zone, J. Geophys. Res., 107, 4380, doi:10.1029/2001JD001525, 2002.

Sassi, F., Kinnison, D., Boville, B. A., Garcia, R. R., and Roble, R.: Effect of El Nino-Southern oscillation on the dynamical, thermal, and chemical structure of the middle atmosphere, J. Geophys. Res., 109, D17108, doi:10.1029/2003JD004434, 2004.

Seppälä, A., Verronen, P. T., Sofieva, V. F., Tamminen, J., Kyrölä, E., Rodger, C. J., and Clilverd, M. A.: Destruction of the tertiary ozone maximum during a solar proton event, Geophys. Res. Lett., 33, L07804, doi:10.1029/2005GL025571, 2006.

Seppälä, A., Verronen, P. T., Clilverd, M. A., Randall, C. E., Tamminen, J., Sofieva, V., Backman, L., and Kyrölä, E.: Arctic and Antarctic polar winter $\mathrm{NO}_{\mathrm{x}}$ and energetic particle precipitation in 2002-2006, Geophys. Res. Lett., 34, L12810, doi:10.1029/2007GL029733, 2007.
Simnett, G. M., and Roelof, E., C.,: Timing of the relativistic proton acceleration responsible for the GLE on 20 January, 2005, 29th International Cosmic Ray Conference Pune, India, 1, 233-236, 3-10 August 2005.

Solomon, S., Rusch, D. W., Gerard, J.-C., Reid, G. C., and Crutzen, P. J.: The effect of particle precipitation events on the neutral and ion chemistry of the middle atmosphere. 2. Odd hydrogen, Planet. Space Sci., 29, 885-892, 1981.

Solomon, S., Reid, G. C., Rusch, D. W., and Thomas, R. J.: Mesospheric ozone depletion during the solar proton event of July 13, 1982, Part II. Comparison between theory and measurements, Geophys. Res. Lett., 10, 257-260, 1983.

Tylka, A. J. and Dietrich, W. F.: A new and comprehensive analysis of proton spectra in ground-level enhanced (GLE) solar particle events, in: Proceedings of the 31st ICRC, Lodz, 7-15 July 2009.

Usoskin, I. G., Tylka, A. J., and Kovaltsov, G. A.: Ionization effect of strong particle events: low-middle atmosphere, in: Proceedings of the 31st ICRC, Lodz, 7-15 July 2009.

Usoskin, I. G., Kovaltsov, G. A., Mironova, I. A., Tylka, A. J., and Dietrich, W. F.: Ionization effect of solar particle GLE events in low and middle atmosphere, Atmos. Chem. Phys., 11, 19791988, doi:10.5194/acp-11-1979-2011, 2011.

Verronen, P. T., Seppälä, A., Kyrola, E., Tamminen, J., Pickett, H. M., and Turunen, E.: Production of odd hydrogen in the mesosphere during the January 2005 solar proton event, Geophys Res. Lett., 33, L24811, doi:10.1029/2006GL028115, 2006.

Verronen, P. T., Rodger, C. J., Clilverd, M. A., Pickett, H. M., and Turunen, E.: Latitudinal extent of the January 2005 solar proton event in the Northern Hemisphere from satellite observations of hydroxyl, Ann. Geophys., 25, 2203-2215, doi:10.5194/angeo25-2203-2007, 2007.

Verronen, P. T., Funke, B., López-Puertas, M., Stiller, G. P., von Clarmann, T., Glatthor, N., Enell, C.-F., Turunen, E., and Tamminen, J.: About the increase of $\mathrm{HNO}_{3}$ in the stratopause region during the Halloween 2003 solar proton event, Geophys. Res. Lett., 35, L20809, doi:10.1029/2008GL035312, 2008.

Versick, S.: Ableitung von $\mathrm{H}_{2} \mathrm{O}_{2}$ aus MIPAS/ENVISATBeobachtungen und Untersuchung der Wirkung von energetischen Teilchen auf den chemischen Zustand der mittleren Atmosphäre, Ph.D. Dissertation (in German), Karlsruher Institute für Technologie, Karlsruhe, Germany, 2010.

Versick, S., Stiller, G., Glatthor, N., Reddmann, T., Ruhnke, R., von Clarmann, T., Höpfner, M., Kiefer, M., Linden, A., Kellmann, S., and Grabowski, U.: MIPAS-observations and model results for $\mathrm{H}_{2} \mathrm{O}_{2}$ with focus on the SPEs 2003 and 2005, poster presented at the 2nd International High Energy Particle Precipitation in the Atmosphere (HEPPA) Workshop, Boulder, CO, 6-8 October, 2009. 